\title{
Bank recapitalization in Europe: informational content in the issuing method
}

\author{
Carlo Chiarella*† \\ Colegio Universitario de Estudios Financieros (CUNEF) \\ Elena Cubillas**t \\ University of Oviedo \\ Nuria Suárez***† \\ Autónoma University of Madrid
}

\begin{abstract}
* Corresponding author. Colegio Universitario de Estudios Financieros (CUNEF). Leonardo Prieto Castro, 2, 28040 Madrid (Spain). Phone: +34 9144808 92. E-mail: carlo.chiarella@ cunef.edu

**University of Oviedo. School of Economics and Business. Avda. del Cristo, s/n. 33006 Oviedo (Spain). Phone: +34 985106203 E-mail: cubillaselena@ uniovi.es
\end{abstract}

***Autónoma University of Madrid. School of Economics and Business. Francisco Tomás y Valiente, 5. 28049 Madrid (Spain). Phone: +34 914975744 E-mail: nuria.suarez@uam.es

\footnotetext{
† We thank Yakov Amihud, Santiago Carbó-Velarde, Pedro Cuadros, Ana I. Fernández, Francisco González and participants at the research seminars held at the Department of Business of the Public University of Navarra (2019), at the Dipartamento di Scienze Economiche, Aziendali e Statistiche of the Università degli Studi di Palermo (2018), and at the Department of Finance at CUNEF (2017) for their helpful comments and suggestions. We also thank participants at the Wolpertinger Conference (2018) in Modena, at the $16^{\text {th }}$ INFINITI Conference on International Finance (2018) in Poznan, at the IFABS Conference (2017) in Oxford, and at the International Risk Management Conference (2017) in Florence. We also acknowledge financial support from the Spanish Ministry of Economy and Competitiveness, Project MINECO-16-ECO2016-79693P. Elena Cubillas and Nuria Suárez also acknowledge financial support from the Spanish Ministry of Economy and Competitiveness, Project MINECO-16-ECO2015-66184-R. Nuria Suárez also acknowledges financial support from the Comunidad de Madrid Project S2015/HUM-3353.
} 


\title{
Bank recapitalization in Europe: informational content in the issuing method
}

\begin{abstract}
In this paper we aim to better understand the behavior of banks and the cost of bank recapitalization during crises. To do so, we study the announcement effect of 124 seasoned equity offerings (SEOs) by 66 listed banks from 20 European Union (EU) countries during the 2006-2016 period. Opposite to what has been observed for nonbanks, where rights issues mitigate investors' adverse selection concerns and wealth transfers for non-participating shareholders, we find that, for SEOs announced by banks during periods of crisis, the abnormal stock returns following the announcement of a rights issue are significantly more negative than for a public offering. More specifically, we find relatively more negative abnormal returns for rights issues of lower relative size, and for issues by larger and less capitalized banks. The same holds for rights issues in countries with relatively higher institutional quality, weaker and less profitable banks, lower restrictions on non-traditional banking activities, and higher bank competition.
\end{abstract}

Keywords: Banks; Regulatory Capital; SEOs; Rights Issues; Information Asymmetries; Agency Conflicts.

JEL classification: G01, G14, G21 


\section{INTRODUCTION}

The majority of papers that have explored the effect of seasoned equity offering (SEOs) announcements and differences across offering methods use a sample of non-bank firms. Their findings are consistent: when a non-bank firm issues new equity, this is interpreted as a signal of overvaluation and, as a result, negative abnormal returns are observed upon the announcement. ${ }^{1}$ Managers, who are better informed than stock market participants, time their offerings to avoid selling undervalued shares, as this would entail a value transfer from current shareholders to new investors. Accordingly, investors, who recognize that the pool of issuing firms is ex-ante overvalued, then respond by discounting the issuer's stock price in the market around the date of the announcement (Myers and Majluf, 1984).

The market reaction to the new issue announcement varies, however, across offering methods (Heinkel and Schwartz, 1986; Eckbo and Masulis, 1992). It is most negative for public offerings and relatively less negative for rights issues, where existing shareholders have the right of first refusal over the additional stock (Armitrage, 1998; Iqbal et al., 2009). Indeed, under this mechanism, where new shares are issued at discount to current shareholders first, adverse selection and wealth transfers are minimized. On the one hand, the discount in the offering price favors shareholder participation and reduces adverse selection concerns. On the other hand, for those shareholders who do not intend to exercise their rights, the proceeds from selling them on the market offset the dilution in the value of their shares due to the new issue, minimizing wealth transfers to participating shareholders and new investors.

\footnotetext{
${ }^{1}$ For a review see Eckbo et al. (2007) or Veld et al. (2015).
} 
However, authors who have explored the announcement effect of SEOs by banks find different results. More specifically, Li et al. (2016) find that abnormal stock returns on SEO announcements for US commercial banks are significantly less negative than those for nonfinancial firms. ${ }^{2}$ The explanation resides in the different information content in SEO announcements by banks compared to non-banks (Poloncheck et al., 1989; Li et al., 2016). First, bank supervision reduces the information content that otherwise would be revealed by an equity issue (Keeley, 1989). Then, by imposing minimum capital ratios that contrast the loss-absorbing capacity of a bank's capital to the risk of its assets (Hellman et al., 2001), bank regulation restricts the freedom of bank managers to time equity offerings (Antzoulatos and Tsoumas, 2014; Elysiani et al., 2014; Khan and Vyas, 2015). This makes investors less wary of the information content in bank SEOs, reducing their adverse selection concerns. As a result, the stock price reaction to the announcement of a new equity issue is less negative.

In this paper we question the general validity of this result showing that the nature and the value to investors of the information content of a bank SEO announcement vary depending on the circumstances under which it occurs. While in normal times a new equity issue may reflect a bank's commitment to comply with capital regulation and disciplined risk-taking, in periods of financial turmoil, SEOs by banks might be interpreted instead as a response to financial difficulties that require additional capital to increase their loss-absorbing ability and comply with high regulatory risk-related capital ratios (Krishnan et al., 2010). Consistent with this argument, $\mathrm{Li}$ et al. (2016) find that the difference between the abnormal announcement returns of banks and non-banks narrowed during the 2007-2009

\footnotetext{
${ }^{2}$ Consistent results also emerge from Slovin et al. (1992) who compare the intra-industry informational externalities of an SEO for banks and industrial firms.
} 
financial crisis period. In this context, the negative market reaction to an SEO announcement by a bank is due not so much to investors' adverse selection concerns, as it is with non-bank issuers, but rather to their inference that the value of the bank's assets is deteriorating and the bank needs additional capital to comply with regulatory requirements and restore its loss-absorbing ability.

Different form Li et. al. (2016), however, we condition the announcement effect of bank SEOs across different offering methods to shed light on the nature and the value of the information revealed to market participants by the relative cost of rights issues and public offerings. Our point is in fact that this information is ancillary to the one revealed by the announcement of an SEO and is ultimately informative on the relative health of the issuer. More specifically, while recapitalization costs are not the only driver of the choice of the issuing method, we argue that the observed outcome is a (noisy) signal to investors of the relative cost of alternative offering methods and, in particular, of expected shareholders' participation and wealth transfers for non-participating shareholders.

On top of direct floatation costs, the cost of raising equity is inversely related to the financial health of the issuer. Recapitalization is more costly for weaker banks. Whenever new stocks are offered below their market price, wealth is transferred from nonparticipating shareholders to participating shareholders and new shareholders, whatever the issuing method.

In principle, the use of rights issues minimizes such wealth transfers by allowing nonparticipating shareholders to avoid the dilution of their claims through the sale of their rights in the secondary market. Therefore, the larger the potential wealth transfers in an 
SEO, the more beneficial is the issuing of rights. However, in practice, shareholders are hardly indifferent. While the direct cost of rights issues and public offerings are independent of the offering price, for rights issues, shareholders incur an additional indirect cost, in the form of transaction costs, if they sell their rights in the secondary market instead of exercising them. At any offering price, this cost depends on all shareholders' willingness to partake in the new issue. The higher is their participation, the more efficient the market for rights and the lower the indirect cost associated with a rights issue. Low shareholder participation results instead in more severe adverse selection problems and frictions in the market for rights, which eventually undermine the mitigation of wealth transfers and raise the indirect cost of a rights issue. Indeed, Eckbo and Masulis (1992) show that if shareholders are more inclined to sell their rights rather than to exercise them to subscribe new shares, transaction costs in the market for rights can become important. These are the result of an adverse selection problem between better informed non-participating shareholders selling their rights and less informed outside investors, resulting in potentially large adverse selection costs of the type analyzed in Myers and Majluf (1984).

Therefore, rights issues are an effective mechanism to mitigate wealth transfers for nonparticipating shareholders only as long as shareholders' participation is high. On the contrary, they become relatively costly and ineffective when expected shareholder participation is low, as gains from the mitigation of wealth transfers are increasingly offset by larger indirect costs. To prevent this from happening, shareholders participation can be incentivized by adjusting the subscription price discount of the rights to make them 
valuable. $^{3}$ However, this might not work during crisis, when shareholders' liquidity constraints and asset allocation restrictions become more binding, hindering shareholders participation and raising the cost of rights issues relative to public offerings. As the relative cost of rights issues increases, some of the stronger banks will then switch to public offerings for issues with smaller wealth transfers. Market participants then infer the pool of rights issuers will be relatively weaker. The stock price of banks issuing rights is then adjusted accordingly, to reflect their relatively poor financial health, larger expected value transfers and in anticipation of higher indirect cost due to frictions in the market for rights.

With this in mind, we test the announcement effect associated with different offering methods in a sample of 124 SEOs by 66 listed banks from 20 EU countries during the 2006-2016 period, using standard event study techniques. More specifically, we exploit the European Union (EU) institutional framework and the recapitalization efforts put in place by banks in the EU between 2006 and 2016.

The reason why the EU represents the ideal setting for our analysis is twofold. First, during the whole sample period, EU regulators have sought to induce banks to reduce their high level of leverage in light of the negative externalities imposed by their fragility on the whole financial system. The advantage is that, with more equity funding, banks can absorb more losses without becoming distressed, defaulting on their debt, requiring resolution or government support. In this respect, banks in the EU have been under pressure to raise capital for a longer period than their US counterparts. Second, contrary to the US where they have almost disappeared (Hansen, 1988), rights issues are mandatory across the EU,

\footnotetext{
${ }^{3}$ In principle, the deeper the discount, the more valuable the right and the more likely the offer will be fully subscribed. Yet, issuers are reluctant to issue rights at deep subscription price discount (Smith, 1977) as it would convey negative information to outside investors about the true value of the issue (Heinkel and Schwartz, 1986).
} 
but this obligation can be waived upon shareholders' approval. ${ }^{4}$ Therefore, if the existing shareholders choose not to waive their right of first refusal, this should be informative for the market about relative recapitalization costs, and more specifically about expected shareholders' participation and wealth transfers for non-participating shareholders.

Our basic results show a relatively more negative abnormal announcement return for bank SEOs conducted in the form of rights issues compared to public offerings, when these occur during the crisis, i.e. when shareholders' willingness to participate should be low and the indirect costs of a rights issue should be more severe. This suggest that the information revealed by the choice of the offering method is specific and supplementary to that conveyed by the announcement of an SEO.

In the specific context of our analysis, adverse selection of the type analyzed in Myers and Majluf (1984) is practically not a concern for investors. New equity issues respond to bank's capital needs rather than attempts to time the market. Therefore, we interpret the market response to the announcement of an SEO's offering method as the result of investors' assessment of the financial health of the bank as well as their response to the frictions they anticipate to emerge in the market for rights. In particular, from the outside investors' point of view, a rights issue where the expected participation of current shareholders is low leads the market participants to infer a bank's relative weakness and anticipate larger wealth transfers.

This argument is in line with the evidence provided by Holderness and Pontiff (2016) showing that: i) the market views a large-wealth-transfer rights issue as the last resort

\footnotetext{
${ }^{4}$ See Art. 29 and Art. 40 of Second Council Directive 77/91/EEC.
} 
method to raise funds; and ii) shareholders, on the losing end of the wealth transfer, sell their shares upon the announcement in anticipation of frictions in the market for rights, inducing negative price pressure. In this respect, it is then also consistent with the selling cost hypothesis by Hansen (1988), which posits a temporary price decline for rights issuers due to the transaction cost disadvantage for shareholders uninterested in subscribing the issue.

To further inform the discussion and interpretation of our findings, we then explore the relation between the type of offering made and the issuer's abnormal returns on the day of the announcement by looking at whether and how it depends on specific characteristics of the offering, of the issuer, of the institutional setting, or of the banking sector.

First, we compare the market response to rights issues carried out during the crisis across specific subsamples formed on the basis of the offering size, the size of the issuer bank, and its capital ratio. Our results show that the negative announcement effect is more relevant in the case of equity offerings of smaller relative size, for larger banks, and for banks with lower capital ratios.

We then examine whether and how the abnormal returns following the announcement of a rights issue during the crisis vary across a broad set of country-level characteristics such as the quality of the institutional framework, the soundness and profitability of the banking sector, and the level of competition among banks. We observe that the announcement effect of a rights issue is more negative in countries with greater investor protection and higher financial transparency. Consistently, we also find that the announcement effect of a rights 
issue is especially negative in less profitable, more unstable and more competitive banking sectors.

Overall, we conclude that the choice of the offering method is more informative about the financial health of the bank within subsamples of SEOs that would ex-ante involve less adverse selection problems. For them the relative costs of alternative offering methods are more comparable and therefore the issuing of rights more clearly reflects the magnitude of the wealth transfers for non-participating shareholders.

To the best of our knowledge our paper is the first one to document such costly frictions in the context of bank recapitalization, providing new insights on how information asymmetry and agency costs can affect the soundness of the financial system during periods of crisis. We believe that the results of our analysis are highly relevant for both investors and bank managers and that its policy implications offer precise guidelines in terms of bank regulation. Our analysis suggests, in fact, that recapitalization costs increase because of the emergence of frictions precisely when banks need capital the most. In particular, when expected shareholders' participation is low, the obligation to issue rights seems to exacerbate agency conflicts instead of protecting shareholders from wealth transfers. The paper then highlights the need to design a system of incentives that helps align the interests of different bank stakeholders at the time of equity issues to prevent shareholders' resistance to bank recapitalization. Costly delays due to frictions in the process of bank recapitalization can in fact undermine the loss-absorbing capacity of banks, with both micro- and macro-prudential implications, as well as their credit supply, with broader economic repercussion. Moreover, as the procyclicality of bank capital requirements has become increasingly central to the policy debate on bank stability, our analysis supports the 
view that calls for regulation to ease the raising of equity in case of need, by providing evidence on the roles played by market regulation and by corporate governance in bank recapitalization.

The rest of the paper is organized as follows. Section 2 describes the data and presents the variables used in our analysis. Section 3 discusses our analysis and presents its main findings. Finally, Section 4 concludes and draws policy implications.

\section{DATA}

Our sample includes all common stock equity offerings in which the issuer is a publicly listed bank domiciled in one of the EU Member States. We consider only primary share offerings and we exclude initial public offerings, for which informational asymmetries are a relatively more significant concern. Data on equity offering announcements by listed banks in the EU, as reported on Bloomberg, are collected from 2006 to 2016, which from the regulatory standpoint corresponds to the life span of Basel II capital requirements.

Our final sample consists of 124 SEOs by 66 banks across 20 different EU countries, of which 82 are rights issues and 42 are public offers. We complement the data on SEOs with issue characteristics and stock returns from Bloomberg, and with a broad set of bank-level financial data from Orbis Bank Focus (Bureau Van Dijk). Banks’ ownership data are from Orbis (Bureau Van Dijk) and information about State aid is from the State Aid Control Section of the European Commission. ${ }^{5}$ Country-level macroeconomic, institutional, and

\footnotetext{
${ }^{5}$ This approach is consistent with other papers in the literature studying bank bailouts, such as Carbó-Valverde et al. (2018). Data include the public records of all cases that have been the object of a Commission decision since 1 January 2000 .
} 
banking market data are from the IMF and the World Bank. Table 1 provides some insights on the composition of the sample.

(Insert Table 1 about here)

More than three-quarters of the SEOs in our sample occurred between 2007 and 2012 reflecting bank efforts to recapitalize during the crisis. Approximately half of the offerings in our sample are from banks domiciled in the UK, France, Germany, Spain or Italy. Overall, there is no clear indication of a prevalence of rights issues over public offerings or vice-versa. Indeed, we have evidence of SEOs in the form of both rights issues and public offerings in most countries and in every year, as well for the same bank that has recurred to SEOs on multiple occasions. Rights issues account for approximately two thirds of the observations in our sample and public offerings for one third, but the relative proportions vary substantially in time and across countries.

Table 2 provides some summary statistics for the SEOs in our sample as well as for the issuing banks and the institutional setup. Our sample is made up of a diverse set of SEOs offered by a heterogeneous group of banks. T-tests allow us to reject the null hypothesis of the equivalence of conditional means across offering types and offering periods in several dimensions. The average issue size is approximately $€ 1.4$ billion but can reach up to more than $€ 15$ billion. There is no significant difference in the offering size between rights issues and public offerings nor across different sub-periods. Yet, in relative terms, the size of the offering, which represents on average approximately $1 \%$ of the total assets of the issuer, is larger for rights issues than for public offerings and is smaller for SEOs launched during 
the crisis. These differences are consistent with our argument that is based on the relative costs of the alternative issuing methods. Wealth transfers increase with the relative size of the issue. Issuing rights mitigates the dilution of current shareholders' claims. All else equal, the larger is the relative size of an SEO the more beneficial is the use of rights issues.

The issuers in our sample are large banks reporting on average total assets of around $€ 408$ billion. Banks opting for rights issues are smaller on average than banks opting for public offerings. Adverse selection problems due to outside investors' asymmetric information are inversely related to the size of the bank. The larger the size of the bank the lower is the adverse selection costs of an SEO and therefore the more comparable are the relative costs of alternative issuing methods. Larger banks are then relatively more likely switch to public offerings for SEOs involving smaller wealth transfers.

Not surprisingly, banks launching SEOs during the crisis are relatively less capitalized, suggesting their goal is to meet capital needs rather than to time the market. Indeed, Table 2 shows that during the crisis market conditions are relatively less favorable for an SEO. Economic growth is lower, and the stock market is more volatile. Banking is less profitable and more competitive. Banks are closer to financial distress and their stocks are more volatile.

Banks in our sample report on average a considerable level of institutional ownership, approximately $20 \%$. Out of the 124 SEOs in our sample, 24 are connected to some form of individual State aid directed to the issuing bank. ${ }^{6}$ The average State ownership stake has been increasing over the sample period and in 45 of the SEOs in our sample the issuing

\footnotetext{
${ }^{6}$ Table A.1 in the Online Appendix shows the list of banks that received State aid during our sample period, the specific type of State aid they received and the corresponding amount. Information about the State ownership prior to the State Aid is also provided.
} 
bank was participated by the State. ${ }^{7}$ Rights issues are less common among banks that received State aid and banks opting for rights issues have on average lower levels of State ownership. These are SEOs involving weaker banks under greater public scrutiny. Shareholders' participation in the SEO is more uncertain, questioning the well-functioning of the market for rights. As a result, SEOs involving smaller wealth transfers are increasingly carried out by means of public offerings.

SEOs generally follow periods of poor stock performance and high volatility. The returns on the stocks of the banks issuing equity are negative in the run up period (on average, $5.3 \%$ ) and more volatile (on average, 51.9\%) compared with the sector (on average, 35.4\%). Banks that announce an SEO perform on average $2.2 \%$ worse than their competitors on the announcement day.

Regarding the institutional setting, rights issues are associated with SEOs carried out under lower investor protection and less information disclosure. These are SEOs for which wealth transfers are more likely and adverse selection costs are more significant. Both suggest greater benefits from issuing rights as long as expected shareholders' participation is high. The opposite holds for bank competition. Rights issues are associated to SEOs by banks whose activities are more regulated.

(Insert Table 2 about here)

\section{EMPIRICAL ANALYSIS}

\footnotetext{
${ }^{7}$ Table A.2 in the Online Appendix provides, in its caption, a list of the banks with State ownership at the time of any one of their SEOs.
} 
We articulate our empirical analysis in three steps. First, we study the determinants of the choice of a rights issue over a public offering, modelling the issuing method as a function of a broad set of offering- and bank-level characteristics, as well as varying economic and financial market conditions. Then, we use conventional event study techniques to compare market reactions upon announcement of right issues and public offerings. Finally, we further explore the relation between the type of offering made and the issuer's abnormal returns on the day of the announcement by looking at whether and how it depends on specific characteristics of the offering, of the issuer, of the institutional setting, or of the banking sector.

Table 3 summarizes the variables used in our empirical analysis, with a brief description and their sources.

(Insert Table 3 about here)

\subsection{The determinants of the choice of a rights issue}

Before we can study the nature and the value of the informational content of an SEO issuing method, we need to inform the discussion by exploring what can explain the reluctance of shareholders to waive their right of first refusal and allow a public offering.

To this aim, we characterize the choice of the issuing method as a function of its potential determinants in a Probit selection model:

$$
\operatorname{Pr}\left(Y_{i, c}=1 \mid X\right)=\Phi\left(X^{T} \beta\right)
$$


where $Y_{i, c}$ is a dichotomous variable, Rights, that defines the choice of the issuing method and takes the value of 1 for SEOs conducted as a rights issue, and 0 otherwise. The vector $\mathrm{X}$ consists of a set explanatory variables that prior work (see for example Ferris et al.,1997 or Slovin et al, 2000) shows to be related with the selection of the offering method. It includes: a bank size, measured in terms of the logarithmic transformation of its total assets; its capital ratio, in terms of book value of equity over total assets; whether it has received State aid; its level of institutional and State ownership; its stock run up before the announcement, volatility and turnover; the relative size of the issue, with respect to the issuer's total assets; the market volatility of banking sector stocks returns; and economic growth.

The results of this analysis for different specifications of the model are presented in Table 4 in the paper. In columns (1), (3), (5) and (7), we report the results of different specifications of our basic model when considering the whole sample period (2006-2016). Columns (2), (4), (6) and (8) present the results of the estimations only for the SEOs carried out during the crisis period (2007-2012).

We find that during periods of crisis the relative size of the offering and the bank's institutional ownership become relevant determinants of the choice of the issuing method. In particular, the higher the offering size the higher the probability of observing a rights issue. The corresponding coefficient is positive and significant at the $1 \%$-level across all model specifications, but only for SEOs carried out during the crisis. During crisis, shareholders' liquidity constraints and/or asset allocation restrictions become more binding, hindering shareholders participation and raising the cost of rights issues relative to public offerings. Still, the larger is the relative size of an SEO the more beneficial is the use of 
rights issues, since wealth transfers increase with the relative size of the issue and issuing rights mitigates the dilution of current shareholders' claims. Therefore, all else equal, shareholders are relatively less likely to waive the obligation to issue rights for larger issues. For these SEOs the gains from the mitigation of wealth transfers overcome the higher indirect costs of issuing rights during the crisis.

Moreover, higher institutional ownership is associated with a higher probability of observing a rights issue. The corresponding coefficient is positive and significant at the 5\%level across all model specifications, but only during the crisis. Institutional shareholders are generally better informed than non-institutional investors. SEOs by banks with higher levels of institutional ownership should then be less affected by asymmetric information and agency costs. This means that the adverse selection problems and the indirect costs of issuing rights during crisis should be relatively milder for SEOs by banks with higher institutional ownership. Therefore, also in this case, shareholders are less likely to waive the obligation to issue rights when institutional ownership is high. Indeed, institutional investors are also more strategic and less affected by liquidity and asset allocation constraints than non-institutional investors. Kothare (1997) and Holderness and Pontiff (2016) that show that institutional ownership increases between the announcement and the expiration of an offering, as institutional investors tend to fully participate or even oversubscribe their shares. This also suggest that during crises rights issues involve wealth transfers among shareholders, typically to institutional shareholders at the expense of other, generally smaller, individual shareholders. As a result, the obligation to issue rights should be less likely waived with higher levels of institutional ownership. 
Other offering- and bank-level characteristics, as well as varying economic and financial market conditions do not seem to play a clear role in explaining the choice of the issuing method. Bank size is negative and significant at the 5\%-level across all model specifications in which it is included, but not during the crisis. Adverse selection problems due to outside investors' asymmetric information are inversely related to the size of the bank. The larger the size of the bank the lower is the adverse selection costs of an SEO and therefore the more likely a public offerings. The opposite holds for State ownership. A higher percentage of state ownership is associated with a lower probability of observing a rights issue during the crisis. The corresponding coefficient is negative and significant at the 10\%-level, consistent with the summary statistics reported in Table 2. Market volatility is only occasionally significant at conventional levels.

(Insert Table 4 about here)

The R-squared statistic is notably higher for the analysis conducted during the crisis period (even columns) compared to the full sample (odd columns). This suggest that the ability of the model to explain the choice of offering method improves during the crisis, when the offering size and institutional ownership become stronger predictors of the decision by shareholders not to waive the obligation to issue rights. Indeed, during crisis, shareholders' liquidity constraints and/or asset allocation restrictions become more binding, hindering shareholders participation and raising the cost of rights issues relative to public offerings. As a result, rights issues become relatively costly and ineffective, as gains from the mitigation of wealth transfers are increasingly offset by larger indirect costs. This however does not hold for all SEOs alike. It rather depends on the size of the issue, as larger issues involve potentially larger wealth transfers, and on the level of institutional ownership, as 
SEOs by banks with higher institutional ownership involve less adverse selection problems associated to the issuing of rights.

\subsection{Stock price announcement effects of rights issues}

To compare the announcement effects of rights issues and public offerings we perform a comprehensive set of empirical tests. Our measure of the market's reaction to different types of offerings focuses on a bank's abnormal returns on the day of the announcement of an SEO with respect to the returns on the same day of the Stoxx Europe Banks index.

We start from simple comparison of the mean returns in rights issues and public offerings. Table 2 shows that on average announcement returns for rights issues are more negative than for public offerings, but we cannot reject the null hypothesis of equality of means across types of offerings. While these tests of conditional means offer initial comparison of the announcement effects of rights issues and public offerings, they do not control for other factors that may affect the returns of the issuer. We therefore perform a multivariate regression analysis that includes control variables that prior work (see Li et al., 2016) shows to be correlated with announcement returns. Our baseline regression is:

$$
Y_{i, c}=\alpha+\beta_{0} \text { Rights }+X^{T} \beta+\delta_{c}+\varepsilon_{i, c}
$$

where the dependent variable is the announcement day abnormal return for the issuing bank and Rights is a dummy variable that takes the value of 1 if an offering is in the form of a rights issue and 0 otherwise. The coefficient $\beta_{0}$ measures the effect of rights issues over public offerings on the announcement day abnormal return. The vector $\mathrm{X}$ consists of a set 
of controls that may affect the issuer's returns at the announcement. These include specific features of the offerings or issuer's characteristics, as well as the relevant macroeconomic conditions. In particular, as regards the offering we consider its relative size, the return on the issuer's stock in the run-up period, as well as its volatility and turnover. We then control for the size of the bank, its capital ratio, whether it has received State aid and its level of State ownership. Finally, we include macroeconomic variables, such as the market volatility of banking sector stocks returns and the growth rate of GDP per capita. $\delta_{c}$ are country-fixed effects to control for time-invariant heterogeneity at the country-level. We include them to ensure that our identification of the effect of explanatory variables comes entirely from within country deviations. $\varepsilon_{i, c}$ is an error term.

The first set of results showing the market reaction to the announcement of a rights issue is presented in Table 5. The dependent variable is the announcement day abnormal returns for the issuing bank. In columns (1), (3), (5) and (7), we report the results of different specifications of our basic model when considering the whole sample period (2006-2016). Columns (2), (4), (6) and (8) present the results of the estimations only for the SEOs carried out during the crisis period (2007-2012).

Consistent with the extant literature on bank SEOs and the smaller adverse selection risk they involve (see Li et al., 2016), in the full sample period we do not observe any negative abnormal return upon the announcement of an SEO or any significant difference between the announcement returns of rights issues and public offerings. Across all the odd columns, the coefficient of the Rights variable, which ranges from -2.23 to -2.56 after controlling for a set of different offer and issuer characteristics, is never statistically significant. Observing a rights issue rather than a public offering is not informative. 
However, we observe different results when we exploit periods of crisis to isolate bank recapitalizations for which the indirect costs of a rights issue should be larger as a result of the frictions that emerge in the market for rights because of low expected shareholders' participation. Indeed, in this specific setting, we find that rights issues are associated with negative abnormal announcement returns that are relatively larger than for public offerings. In all even columns, the coefficient of the Rights variable is negative and statistically significant. Rights issues in periods of crisis are associated with an abnormal announcement return that is from 5.14 to 5.82 percentage points more negative than for a public offer, depending on the model specification. We interpret investors' negative response to the announcement of a rights issue as a consequence of their assessment of the financial health of the bank as well as their response to the frictions they anticipate to emerge in the market for rights. Upon observing a rights issue during a period of crisis, investors anticipate relatively larger wealth transfers. Indeed, as the relative cost of rights issues increases, some of the stronger banks will switch to public offerings for issues with smaller wealth transfers. Market participants then infer the pool of rights issuers will be relatively weaker and respond more negatively to their announcement. This interpretation of the results is in line with the evidence provided by Holderness and Pontiff (2016) showing that: i) the market views a large-wealth-transfer rights issue as the last resort method to raise funds; and ii) shareholders, on the losing end of the wealth transfer, sell their shares upon the announcement in anticipation of frictions in the market for rights, inducing negative price pressure. In this respect, it is then also consistent with the selling cost hypothesis by Hansen (1988), which posits a temporary price decline for rights issuers due to the transaction cost disadvantage for shareholders uninterested in subscribing the issue. 
During the crisis, investors respond relatively more negatively to the announcement of an SEO by banks that received State aid or banks in which the State has an ownership stake. Their corresponding coefficients are negative and significant. Remarkably, the effect of State ownership prevails over that of State aid once they are jointly controlled for. This is consistent with the fact that for the banks in our sample State ownership is largely the result of State aid in the form of recapitalization. Nonetheless, rights issues are still associated with negative abnormal announcement returns that are relatively larger than for public offerings even after controlling for State aid and State ownership.

With respect to other explanatory variables, we can see that the stock run up is positively associated with market returns in most of the estimations presented in Table 5. This confirms that investors do not respond to all SEO announcements in the same way. They reward those by banks that have performed better in the recent past and penalize those by banks that have performed worse. Consistently, the corresponding coefficient is positive and significant, except for model specifications that also control for State Aid and State ownership which are themselves proxies of poor performance during the crisis.

(Insert Table 5 about here)

\subsection{Comparative analysis of announcement effects across offer, issuer and country- level characteristics}

We then exploit the heterogeneity across the SEOs in our sample in terms of a broad set of offer, issuer and country-level characteristics to further explore the relation between the type of offering made and the issuer's abnormal returns on the day of the announcement and provide additional evidence of whether and how it varies in the cross-section. 
More specifically, we compare the market response to the announcement of a rights issue by re-estimating model [2] within specific subsamples obtained on the basis of the median value of a few selected offer, issuer and country-level characteristics. These include the relative size of the offer, the size of the issuer, its capital ratio, as well as country-level measures of institutional quality, country-level measures of the soundness and the profitability of the banking sector, and the level of competition in the banking industry. We focus only on the crisis period and on the baseline model specification of column (4) in Table 5 .

Overall, we find that the choice of the offering method is more informative about the financial health of the bank within subsamples of SEOs that would ex-ante involve less adverse selection problems. For them the relative costs of alternative offering methods are more comparable and therefore the issuing of rights more clearly reflects the magnitude of the wealth transfers for non-participating shareholders. As result market participants adjust their valuation of the stock of the issuer more severely.

\subsubsection{Relative offering size and bank characteristics}

Market reaction to the announcement of an SEO could vary significantly depending on the offering and the issuer's characteristics, even when the issuing method is the same. Analogously, offering and bank characteristics can alleviate or increase concerns about expected wealth transfers and indirect costs of issuing rights, eventually concurring to determine the relative cost of alternative issuing methods.

First, we split our sample around the median value of the offering size, the issuer's size and its capital ratio. The results of this analysis are presented in Table 6. Columns (1), (3) and 
(5) show the results obtained for SEOs of larger relative size, larger banks, and banks with higher capital ratios, respectively. Columns (2), (4) and (6) present the results for smaller SEOs, smaller banks, and banks with lower capital ratios, respectively.

Splitting the sample around the median value of Relative Size, we find that the market response to the announcement of a rights issue is relatively more negative for smaller issues. Those are SEOs for which both wealth transfers and indirect costs of issuing rights should be relatively milder. The coefficient for the variable Rights is negative and statistically significant for the subsample of small SEOs whose relative size is below the median, in column (2), but is not significant for larger SEOs, in column (1). The Wald test reported at the bottom of the table allows us to reject the null hypothesis of the equality of coefficients across the two specifications.

In a similar vein, splitting the sample around the median value of Bank Size we find that the market response to the announcement of a rights issue is relatively more negative when the issuer is a large bank. Indirect costs of rights issues should be lower for larger banks because of lower information asymmetry. The coefficient for Rights is negative and statistically significant only for banks whose size is above the median, in column (3). The corresponding Wald test allows us to reject the null hypothesis of the equality of coefficients for small and large banks.

Finally, we split the sample around the median value of Equity. The results in columns (5) and (6) show that the market response to the announcement of a rights issue is relatively more negative when the issuer is less capitalized. A smaller equity capital buffer means lower loss absorbing capacity and greater risk. The cost of recapitalization for less 
capitalized issuers should then be larger. The coefficient for Rights is negative and statistically significant only for banks whose capital ratio is below the median. The corresponding Wald test allows us to reject the null hypothesis of the equality of coefficients for less and more capitalized banks.

(Insert Table 6 about here)

\subsubsection{Institutional quality and banking market characteristics}

Market reaction to the announcement of an SEO may differ across countries even when the issuing method is the same, as institutional quality and bank market characteristics in each country may lead to differences in terms of shareholders protection from wealth transfers and indirect costs of issuing rights.

We first split the sample around the median value of two traditional measures of institutional quality: Investor Protection and Disclosure Index. The results of this analysis are shown in the four first columns of Table 7 . The market response to the announcement of a rights issue is relatively more negative, either when investors are more protected, or when they are more informed, which corresponds to higher levels of Investor Protection and Disclosure Index. In this context, adverse selection problems are less severe and the indirect costs of rights issues should be lower. Consistently, the variable Rights, is negative and statistically significant only in columns (1) and (3). The corresponding Wald tests

reported at the end of the table allow us to reject the null hypothesis of the equality of coefficients across different specifications. 
In the same vein, we expect to observe different results across countries according to specific bank market characteristics. We split our sample around the median value of two variables: Banking Sector Z-score and Banking Sector ROE. The results of this analysis are shown in columns (5) to (8) of Table 7. The coefficient for Rights is negative and statistically significant only in the subsamples in which the Z-score and the ROE are below their median values, in columns (6) and (8). This suggests that market response to the announcement of a rights issue is relatively more negative when the issuer operates in a banking sector that is more fragile and less profitable. The corresponding Wald tests reported at the end of the table allow us to reject the null hypothesis of the equality of coefficients across different specifications

Finally, we split our sample around the median value of Banking Sector Lerner Index and Bank Activities Restrictions. The results of this analysis are shown in columns (9) to (12) of Table 6. The coefficient for Rights is negative and statistically significant only in subsamples in which bank activities are less restricted and competition is more intense (i.e., the Lerner Index is below the median), as shown in columns (10) and (12). This suggests that market response to the announcement of a rights issue is relatively more negative when competition is higher and banks are less restricted so can engage in risky non-traditional activities. These conditions should lead to relatively more bank risk taking and more asymmetric information. The corresponding Wald tests reported at the end of the table allow us to reject the null hypothesis of the equality of coefficients across different specifications.

(Insert Table 7 about here) 


\subsection{Robustness checks}

In previous sections, we have shown that the stock market reaction to the announcement of a bank rights issue during the crisis is negative and that its magnitude varies across banks and countries, depending on how informative the issuing method is about a bank's financial health and relative recapitalization costs. In further analyses, presented in the Online Appendix, we check the robustness of our basic set of results and their generalizability in alternative empirical settings.

First, we corroborate our view that the choice of the issuing method conveys specific information, that is different from and complementary to that revealed by the fact that the bank is seeking additional capital. To this aim, we replicate our analysis in [2] for a subsample of SEOs, where we believe the choice of the issuing method should rather convey relatively more information about expected shareholders' participation and wealth transfers for non-participating shareholders. More specifically, we focus only on the 65 SEOs in our sample conducted by banks that issued multiple times during the crisis and then split this subsample between the 42 banks that used both offering methods and the 23 banks that only used one method. Our intuition is that the choice of issuing method should be more uncertain and therefore more informative within the subsample of SEOs by issuers that used both methods. We find rights issues are associated with more severe announcement returns only in the subsample of recurrent issuers that use both methods (see Table A.3 in the Online Appendix). In further robustness tests, available upon request, we also examine if our results hold when controlling for the number of previous SEOs by each bank. This is because previous SEOs by the bank might lead to different market reactions 
because of the different degree of information revealed upon the announcement of a rights issue. Our findings continue to hold.

Second, we test whether our results hold when the choice between a rights issues and a public offering is not considered fully exogenous but is in part driven by the expected announcement returns. In such a setting, where observations are not randomly assigned to different groups, ordinary least square regressions may not provide consistent estimates. To this aim, we perform a two-stage Heckman (1979) regression analysis that controls for the potential endogeneity between the choice of the type of offering and the announcement effects. Our results still hold when we exogenously identify the choice of the offering method by means of the proportion of the issuer's shares outstanding that are owned by institutional investors (see Table A.3 in the Online Appendix).

\section{CONCLUSIONS}

The paper extends previous analyses on the effects of SEOs announcements in many ways. Most of the papers in the literature use a sample of non-bank firms (see review by Veld et al., 2015). Then, authors who also consider banks mostly focus on the US as the country under analysis and do not distinguish between alternative issuing methods (Poloncheck et al., 1989; Li et al., 2016). Our paper, on the other hand, examines the announcement effect of 124 SEOs by 66 banks from 20 European countries during the 2006-2016 period, conditioning the analysis across different offering methods to shed light on the nature and the value of the information revealed to market participants by the relative cost of rights issues and public offerings. 
Opposite to what has been observed for non-banks, we find that abnormal stock returns following the announcement of a rights issue during a crisis period are significantly more negative than for a public offering. We interpret investors' negative response to the announcement of a rights issue as a consequence of their assessment of the financial health of the bank as well as their response to the frictions they anticipate to emerge in the market for rights. In particular, we argue that upon the announcement of a rights issue during a period of crisis, the issuer's stock price adjusts to reflect new information about relative recapitalization costs across issuing methods, and more specifically about expected shareholders' participation and wealth transfers for non-participating shareholders. This information is specific to the choice of the offering method and supplementary to that conveyed by the announcement of an SEO.

Then we find that the negative abnormal return upon the announcement of a rights issue is larger in the case of relatively smaller equity offerings, larger banks and banks with lower capital ratios. Similarly, our empirical findings show that the negative abnormal return upon the announcement of a rights issue is larger in countries with relatively higher institutional quality, weaker and less profitable banks, lower restrictions on non-traditional banking activities, and higher competition. Overall, we conclude that the choice of the offering method is more informative about the financial health of the bank within subsamples of SEOs that would ex-ante involve less adverse selection problems. For them the relative costs of alternative offering methods are more comparable and therefore the issuing of rights more clearly reflects the magnitude of the wealth transfers for nonparticipating shareholders. 
In terms of policy implications, our paper clarifies the regulatory and institutional characteristics that could favor the alignment of the interests of the different bank stakeholders when the bank issues new equity. Indeed, our findings shed light on costly frictions for raising equity capital precisely when banks most need it. Assuming capital need, successful bank recapitalization may require new shares being offered at large discount (Beccalli and Frantz, 2016). Yet, our analysis highlights that rights issues may not fully offset wealth transfers when expected shareholders' participation to the offer is low. As a result, the threat of wealth transfers can possibly create incentives for shareholders to resist recapitalizations, while a reduction in leverage would be in the general interest, since bank distress or insolvency have negative external effects and social cost. In this respect, the results of our paper provide new insights on how frictions in bank recapitalization can affect the soundness of the financial system and economic growth. Shareholder resistance to bank recapitalization may in fact have implications not only for the loss-absorbing capacity of banks, but also for their credit supply. Consistent with the more general framework of wealth transfers and agency conflicts that originate from debt overhang (Myers, 1977), banks may choose not to make new loans if more equity funding is needed to finance them, or may decide to deleverage by shrinking the asset side of their balance sheet, selling assets and reducing lending.

Moreover, as the procyclicality of bank capital requirements has become increasingly central to the policy debate on bank stability, our analysis provides evidence on the emergence of frictions in access for banks to equity in capital markets precisely when their recapitalization is most urgent and would be most beneficial. This calls for regulation to ease the raising of equity in case of need, which we do not see as a substitute for capital 
requirements but, rather, as a necessary complement to them. While the latter are meant to enhance a bank's resiliency by disciplining risk-taking, the former would improve to their capacity to absorb losses. In fact, our analysis provides evidence on the roles played by market infrastructure and corporate governance in bank recapitalization. In particular, on the one side, the frictions that emerge in the market for rights when expected shareholders' participation is low pose new questions to European policymakers on the obligation to issue rights, also in light of their disappearance in the US. On the other side, the particular interests of different shareholders that emerge in this context raise new questions on the type of ownership structure, if any, that would make the system safer.

\section{REFERENCES}

Admati, A.R., DeMarzo, P.M., Hellwig, M.F., Pfleiderer, P., 2010. Debt Overhang and Capital Regulation. Working Paper.

Admati, A.R., DeMarzo, P.M., Hellwig, M.F., Pfleiderer, P., 2012. Fallacies, Irrelevant Facts, and Myths in the Discussion of Capital Regulation: Why Bank Equity is Not Expensive. Rock Center for Corporate Governance at Stanford University Working Paper No. 86, Stanford Graduate School of Business Research Paper No. 2056, Max Planck Institute for Research on Collective Goods Preprint 2010/42.

Antzoulatos, A.A., Tsoumas, C., 2014. Institutions: moral hazard and expected government support of banks. Journal of Financial Stability 15, 161-171.

Armitage, S., 1998. Seasoned equity offers and rights issues: a review of the evidence. European Journal of Finance 4, 29-59.

Barclay, M.J., Litzenberger, R.H., 1988. Announcement effects of new equity issues and the use of intraday price data. Journal of Financial Economics 21, 213-232.

Barth, J.R., Caprio Jr., G., Levine, R., 2006. Rethinking bank regulation: till angels govern. University Press, Cambridge.

Beccalli, E., Frantz, P., 2016. Why are some banks recapitalized and others taken over?. Journal of International Financial Markets, Institutions and Money 45, 79-95. 
Berk, J., DeMarzo, P., Harford, J., 2012. Fundamentals of corporate finance, seconded. Prentice Hall, Boston, MA.

Bolton, P., Freixas, X., 2006. Corporate Finance and the Monetary Transmission Mechanism . Review of Financial Studies 19, 829-870.

Bris, A., Cabolis, C., 2008. The value of investor protection: Firm evidence from cross-border mergers. Review of Financial Studies 21, 605-649.

Campa, J.M., Kedia, S., 2002. Explaining the diversification discount. Journal of Finance 57, 17311762.

Carbó-Valverde, S., Cuadros-Solas, P., Rodríguez-Fernández, F., 2018. Do bank bailouts have an impact on the underwriting business?. Working Paper.

Chaudhuri, R., Seo, H., 2012. An agency theory explanation of SEO underperformance: Evidence from dual-class firms. Journal of International Financial Markets, Institutions and Money 22(3), 575-588.

Chen, H. C., Shu, P. G., Chiang, S. J., 2011. The choice between bookbuilding and fixed-price offering: Evidence from SEOs in Taiwan. Journal of International Financial Markets, Institutions and Money 21(1), 28-48.

Corwin, S.A., 2003. The determinants of underpricing for seasoned equity offers. Journal of Finance 58, 2249-2279.

Eckbo, B.E., Masulis, R.W., 1992. Adverse selection and the rights offer paradox. Journal of Financial Economics 32, 293-332.

Elyasiani, E., Mester, L.J., Pagano, M.S., 2014. Large capital infusions investor reactions, and the return and risk-performance of financial institutions over the business cycle. Journal of Financial Stability 11, 62-81.

Ferris, S. P., Noronha, G., McInish, T. 1997. New equity offerings in Japan: an examination of theory and practice. Journal of International Financial Markets, Institutions and Money 7, 185-200.

Flannery, M., 1998. Using market information in prudential bank supervision: a review of the US empirical evidence. Journal of Monetary, Credit and Banking 30, 273-305.

García-Palacios, J.H., Hasman, A., Samartín, M., 2014. Banking crises and government intervention. Journal of Financial Stability 15, 32-42. 
Hansen, R.S., 1988. The demise of the rights issue. Review of Financial Studies 1(3), 289-309.

Heckman, J., 1979. Sample selection bias as a specification error. Econometrica 47, 153-161.

Heinkel, R., Schwartz, E. 1986. Rights versus underwritten offerings: An asymmetric information approach. Journal of Finance, 41 (March), 1-18.

Hellmann, T. F., Murdock, K. C., Stiglitz, J. E., 2000. Liberalization, moral hazard in banking, and prudential regulation: Are capital requirements enough? American Economic Review 90 (1), 147-165.

Hoggarth, G., Reidhill, J., Sinclair, P., 2004. On the resolution of banking crises: Theory and evidence. Bank of England, London.

Holderness, C. G., Pontiff, J., 2016. Shareholder nonparticipation in valuable rights offerings: New findings for an old puzzle. Journal of Financial Economics 120(2), 252-268.

Hovakimian A., Kane, E. J., 2000. Effectiveness of capital regulation at US commercial banks, 1985-1994. Journal of Finance 55, 451-469.

Iqbal, A., Espenlaub, S., Strong, N. 2009, "Earnings management around UK open offers", European Journal of Finance 15 (1), 29-51.

Kashyap, Anil, K., Samuel Hanson and Jeremy C. Stein (2010), “An Analysis of the Impact of "Substantially Hightened" Capital Requirements on Large Financial Institutions", Working Paper.

Kaufman, G.G., 2015. Too big to fail in banking: what does it mean? Journal of Financial Stability $13,214-223$.

Keeley, M.C., 1989. The stock price effects of bank holding company securities issuance. Economic Review Win, 3-19.

Khan, M., Vyas, D., 2015. The capital purchase program and subsequent bank SEOs. Journal of Financial Stability 18, 91-105.

Kothare, M., 1997. The effects of equity issues on ownership structure and stock liquidity: A comparison of rights and public offerings. Journal of Financial Economics 43(1), 131-148.

Krishnan, C.N.V., Ergungor, O.E., Laux, P.A., Singh, A.K., Zebedee, A.A., 2010. Examining bank SEOs: are offers made by undercapitalized banks different? Journal of Financial Intermediation 19, 207-234. 
Li, H., Liu, H., Siganos, A., Zhou, M., 2016. Bank regulation, financial crisis, and the announcement effects of seasoned equity offerings of US commercial Banks. Journal of Financial Stability 25, 37-46.

Mikkelson, W.H., Partch, M.M., 1986. Valuation effects of security offerings and the issuance process. Journal of Financial Economics 15, 30-60.

Myers, S. C., 1977. Determinants of Corporate Borrowing. Journal of Financial Economics 5, 147175.

Myers, S.C., Majluf, N.S., 1984. Corporate Financing and Investment Decisions when Firms Have Information that Investors do not Have. Journal of Financial Economics 13, 187-222.

Polonchek, J., Slovin, M.B., Sushka, M.E., 1989. Valuation effects of commercial bank security offerings: a test for information hypothesis. Journal of Banking and Finance 3, 443-461.

Repullo, R., 2004. Capital requirements, market power, and risk-taking in banking. Journal of Financial Intermediation 13, 156-182.

Slovin, M. B., Sushka, M. E., Lai, K. W., 2000. Alternative flotation methods, adverse selection, and ownership structure: evidence from seasoned equity issuance in the UK. Journal of Financial Economics 57(2), 157-190.

Slovin, M. B., Sushka, M. E., Polonchek, J. A., 1992. Informational externalities of seasoned equity issues: differences between banks and industrial firms. Journal of Financial Economics $32(1), 87-101$.

Smith Jr, C. W., 1977. Alternative methods for raising capital: Rights versus underwritten offerings. Journal of Financial Economics, 5(3), 273-307.

Smith, G., 1986. Investment banking and the capital acquisition process. Journal of Financial Economics 15, 3-29.

Veld, C., Verwijmeren, P., Zabolotnyuk, Y., 2015. Wealth effects of seasoned equity offerings: a meta analysis. Working paper. 


\section{Table 1: Sample description}

This table provides details on the composition of our sample of seasoned equity offerings. Observations are classified by type of offering and the country of domicile of the issuer. The year of the issue is reported in parenthesis.

\begin{tabular}{|c|c|c|}
\hline Country & Rights Issues & Public Offerings \\
\hline Austria & $\begin{array}{l}\text { BKS Bank (2016); Erste Group Bank (2009, } \\
\text { 2013); Oberbank }(2006,2009)\end{array}$ & Erste Group Bank (2013); Oberbank (2014) \\
\hline Belgium & & KBC Groep (2012) \\
\hline Bulgaria & Central Cooperative Bank $(2007,2011)$ & \\
\hline Denmark & $\begin{array}{l}\text { Andelskassers Bank (2015); Danske Bank } \\
\text { (2011); Oestjydsk Bank (2011, 2013, 2015); } \\
\text { Skjern Bank (2012); Spar Nord Bank (2012); } \\
\text { Totalbanken (2012); Vestjysk Bank (2012) }\end{array}$ & Danske Bank (2006, 2012); Jyske Bank (2012) \\
\hline Finland & Alandsbanken (2011); Pohjola Bank (2009) & \\
\hline France & $\begin{array}{l}\text { BNP Paribas (2009); Crédit Agricole (2006, } \\
\text { 2008); Natixis (2008); Socièté Générale (2006, } \\
2008,2009)\end{array}$ & \\
\hline Germany & $\begin{array}{l}\text { Areal Bank (2011); Deutsche Bank (2010, 2013); } \\
\text { Deutsche Postbank (2008); DVB Bank SE } \\
\text { (2008); HSBC Trinkaus \& Burkhardt (2010, } \\
\text { 2014); IKB Deutsche Industriebank (2008); Net- } \\
\text { M Privatbank } 1891 \text { (2009); UmweltBank (2016) }\end{array}$ & Areal Bank (2011); Deutsche Bank $(2008,2010)$ \\
\hline Greece & $\begin{array}{l}\text { Piraeus Bank }{ }^{8}(2007,2009,2011) \text {; TT Hellenic } \\
\text { Postbank (2009); }\end{array}$ & \\
\hline $\begin{array}{l}\text { Ireland } \\
\end{array}$ & Bank of Ireland $(2010,2011)$ & Bank of Ireland $(2010,2010,2011)$ \\
\hline Italy & $\begin{array}{l}\text { Banca Popolare di Milano (2009, 2011); Banca } \\
\text { Popolare di Spoleto (2009); Credito Emiliano } \\
\text { (2008); UBI Banca (2009); UniCredit (2010, } \\
\text { 2011); }\end{array}$ & Intesa Sanpaolo (2007) \\
\hline Lithuania & $\begin{array}{l}\text { AB Ukio Bankas (2011); Siauliu Bankas (2008, } \\
\text { 2010) }\end{array}$ & AB Ukio Bankas (2010) \\
\hline Luxembourg & Espirito Santo Financial Group (2012) & Espirito Santo Financial Group (2008) \\
\hline Netherlands & SNS Reaal (2009) & \\
\hline $\begin{array}{l}\text { Poland } \\
\end{array}$ & $\begin{array}{l}\text { Bank BHP (2009); Bank Millenium (2010); BRE } \\
\text { Bank (2010); Powszechna Kasa Oszczednosci } \\
\text { Bank (2009) }\end{array}$ & $\begin{array}{l}\text { Bank Ochrony Srodowiska (2016); Bank Polska } \\
\text { Kasa Opieki }(2007,2009)\end{array}$ \\
\hline Portugal & $\begin{array}{l}\text { Banco BPI (2008, 2012); Banco Comercial } \\
\text { Portugues }(2008,2011,2012) ; \text { Banco Espirito } \\
\text { Santo (2006) }\end{array}$ & Banco Comercial Portugues (2012) \\
\hline Romania & $\begin{array}{l}\text { Banca Comerciala } \\
\text { Transilvania Bank (2008) }\end{array}$ & \\
\hline Slovenia & & Nova Kreditna Banka Maribor (2011) \\
\hline Spain & $\begin{array}{l}\text { Banco Sabadell (2012, 2013); Banco Santander } \\
\text { (2008); Banco de Valencia (2007); Bankinter } \\
\text { (2009); BBVA (2010) }\end{array}$ & $\begin{array}{l}\text { Banco Sabadell }(2009,2011) \text {; Banco Santander } \\
\text { (2015); BBVA }(2006,2014)\end{array}$ \\
\hline Sweden & $\begin{array}{l}\text { Nordea Bank (2009); Skandinaviska Enskilda } \\
\text { Banken (2009); Swedbank }(2008,2009,2010)\end{array}$ & \\
\hline United Kingdom & $\begin{array}{l}\text { HSBC (2009); Lloyds Banking Group (2009); } \\
\text { Royal Bank of Scotland Group (2009, 2014); } \\
\text { Standard Chartered }(2008,2010)\end{array}$ & $\begin{array}{l}\text { HSBC (2009); Lloyds Banking Group (2008, } \\
\text { 2009, 2009, 2013, 2015); Royal Bank of } \\
\text { Scotland Group }(2008,2009,2012,2013,2013, \\
\text { 2014); Standard Chartered (2006, 2008, 2009, } \\
\text { 2010, 2015) }\end{array}$ \\
\hline
\end{tabular}

\footnotetext{
${ }^{8}$ Previously, General Bank of Greece. In December 2012 all shares were sold to Piraeus Bank.
} 
Table 2: Summary statistics

This table reports summary statistics for all SEOs in our sample. It includes information on a set of variables ranging from announcement effects, to offering and issuer specific characteristics, macroeconomic conditions, institutional quality and banking sector metrics. A description of the variables and the relevant sources is provided in Table 3. Equivalences of means across subsamples, formed according to the type of offering as well as for crisis years (2007-2012) and no crisis years (2006, 2013-2016), are tested by means of T-tests. Diff. is the difference between the conditional means (i.e., rights issues vs. public offerings, and crisis years vs. no crisis years) and the corresponding $\mathrm{t}$-statistics are reported in parenthesis. ***, ** and $*$ indicate levels of significance of $1 \%, 5 \%$, and $10 \%$, respectively.

\begin{tabular}{|c|c|c|c|c|c|c|}
\hline & \multicolumn{2}{|c|}{$\begin{array}{l}\text { All sample period } \\
(2006-2016)\end{array}$} & \multicolumn{2}{|c|}{$\begin{array}{c}\text { Crisis years }(2007-2012) \\
\text { versus no crisis years }\end{array}$} & \multicolumn{2}{|c|}{$\begin{array}{c}\text { Rights issues } \\
\text { versus Public offerings }\end{array}$} \\
\hline & Mean & St.Dev. & Diff. & t-stat & Diff. & t-stat \\
\hline$A R s(\%)$ & -2.17 & 7.25 & -1.25 & $(-0.80)$ & -1.37 & $(-1.00)$ \\
\hline Market Volatility (\%) & 35.43 & 15.22 & $19.88 * * *$ & $(7.23)$ & 4.33 & $(1.51)$ \\
\hline Stock Volatility (\%) & 51.93 & 30.49 & $27.15^{* * *}$ & $(4.45)$ & -0.20 & $(-0.03)$ \\
\hline Stock Run-up (\%) & -5.29 & 27.46 & -3.51 & $(-0.59)$ & -3.35 & $(-0.64)$ \\
\hline Turnover (\%) & 0.98 & 1.76 & 0.07 & $(0.19)$ & 0.26 & $(0.76)$ \\
\hline Offer size ( $€$ Bn.) & 1.36 & 2.44 & 0.01 & $(0.01)$ & 0.49 & $(1.07)$ \\
\hline Relative Size (\% total assets) & 1.15 & 1.70 & $-0.76 * *$ & $(-2.12)$ & $0.88 * * *$ & $(2.81)$ \\
\hline Bank Size (€ Bn.) & 408.75 & 629.26 & -115.50 & $(-0.85)$ & $-289.52 * *$ & $(-2.47)$ \\
\hline Equity (\% total assets) & 7.79 & 11.33 & $-9.13 * * *$ & $(-3.97)$ & 0.71 & $(0.33)$ \\
\hline Aided bank & 0.19 & 0.40 & -0.12 & $(-1.40)$ & $-0.14 *$ & $(-1.87)$ \\
\hline State Ownership (\%) & 5.68 & 16.11 & $-7.80 * *$ & $(-2.29)$ & $-8.39 * * *$ & $(-2.82)$ \\
\hline Institutional Ownership (\%) & 20.00 & 24.67 & -6.37 & $(-1.20)$ & 4.08 & $(0.87)$ \\
\hline$\triangle G D P p c(\%)$ & -0.16 & 3.52 & $-1.86 * *$ & $(-2.51)$ & -0.68 & $(-1.01)$ \\
\hline Investor Protection & 6.08 & 1.29 & -0.13 & $(-0.46)$ & $-1.08 * * *$ & $(-4.83)$ \\
\hline Disclosure Index & 6.87 & 2.24 & -0.21 & $(-0.44)$ & $-1.38 * * *$ & $(-3.39)$ \\
\hline Banking sector Zscore & 9.95 & 6.80 & $-6.39 * * *$ & $(-3.88)$ & 1.15 & $(0.85)$ \\
\hline Banking sector ROE & 0.12 & 19.02 & $-9.89 * *$ & $(-2.47)$ & 4.26 & $(1.18)$ \\
\hline Bank Activities Restrictions & 7.94 & 2.50 & $1.13^{* *}$ & $(2.12)$ & $1.75^{* * *}$ & (3.89) \\
\hline Banking sector Lerner Index & 0.20 & 0.11 & $-0.05^{* *}$ & $(-2.07)$ & -0.02 & $(-0.73)$ \\
\hline
\end{tabular}


Table 3: Description of variables and sources

This table describes the variables used in the analysis and the corresponding sources.

\begin{tabular}{|c|c|c|}
\hline Variable & Description & Source \\
\hline ARs & Announcement-day abnormal returns over the Stoxx Europe Banks Index & Bloomberg \\
\hline Market Volatility & $\begin{array}{l}\text { Volatility of daily returns on the Stoxx Europe Banks Index over the period [- } \\
261 ;-1] \text { with respect to the announcement date of the new issue }\end{array}$ & Bloomberg \\
\hline Stock Volatility & $\begin{array}{l}\text { Volatility of the issuer's daily stock returns over the period }[-261 ;-1] \text { with } \\
\text { respect to the date of announcement of the new issue }\end{array}$ & Bloomberg \\
\hline Stock Run-Up & $\begin{array}{l}\text { Return on the issuer's stock over the period }[-61 ;-1] \text { with respect to the date of } \\
\text { announcement of the new issue }\end{array}$ & Bloomberg \\
\hline Turnover & $\begin{array}{l}\text { Average number of shares traded daily in the period }[-61 ;-1] \text { with respect to } \\
\text { the announcement date over the number of shares outstanding }\end{array}$ & Bloomberg \\
\hline Relative Size & $\begin{array}{l}\text { Market value of the shares offered scaled by the book value of the issuer's } \\
\text { assets }\end{array}$ & Bloomberg \\
\hline Bank size & $\begin{array}{l}\text { Logarithmic transformation of the book value of the issuer's assets as reported } \\
\text { at the end of the last fiscal year before the announcement of the new issue }\end{array}$ & Orbis Bank Focus \\
\hline Equity & $\begin{array}{l}\text { Book value of the issuer's equity over its total assets as reported at the end of } \\
\text { the last fiscal year before the announcement of the new issue }\end{array}$ & Orbis Bank Focus \\
\hline Aided Bank & $\begin{array}{l}\text { A dummy that takes a value of } 1 \text { if the bank issuer receives State aid in the } \\
\text { same year of the SEO and } 0 \text { otherwise. }\end{array}$ & European Commission \\
\hline State Ownership & $\begin{array}{l}\text { Percentage of shares outstanding owned by State at the end of the year prior to } \\
\text { the SEO. }\end{array}$ & Orbis \\
\hline Institutional Ownership & Percentage of shares outstanding owned by institutional investors & Orbis \\
\hline$\Delta \mathrm{GDPpc}(\%)$ & $\begin{array}{l}\text { Annual growth rate of the per capita Gross Domestic Product in the country } \\
\text { where the issuer is domiciled }\end{array}$ & IMF \\
\hline Investor Protection & $\begin{array}{l}\text { Annual index of protection of investors' rights as reported in the World Bank } \\
\text { Doing Business Database }\end{array}$ & World Bank \\
\hline Disclosure Index & $\begin{array}{l}\text { Annual index of disclosure of financial information included in the World } \\
\text { Governance Indicators periodically computed by the World Bank }\end{array}$ & World Bank \\
\hline Banking sector Zscore & $\begin{array}{l}\text { The probability of default of a country's commercial banking system reported } \\
\text { in the Global Financial Development Database of the World Bank. It } \\
\text { compares the buffer of a country's commercial banking system (capitalization } \\
\text { and returns) with the volatility of these returns }\end{array}$ & World Bank \\
\hline Banking sector ROE & $\begin{array}{l}\text { Commercial banks' after-tax net income to yearly averaged equity reported in } \\
\text { the Global Financial Development Database of the World Bank }\end{array}$ & World Bank \\
\hline Bank Activities Restrictions & $\begin{array}{l}\text { Index of the extent to which non-traditional banking activities (i.e. real estate, } \\
\text { insurance, securities and ownership of non-financial firms) are restricted, as } \\
\text { computed by Barth et al. (2012) and reported on the World Bank Regulation } \\
\text { and Supervision Database }\end{array}$ & World Bank \\
\hline Banking sector Lerner Index & $\begin{array}{l}\text { Annual measure of the level of bank market power, as reported in the Global } \\
\text { Financial Development Database of the World Bank }\end{array}$ & World Bank \\
\hline
\end{tabular}




\section{Table 4: The determinants of the choice of offering method}

This table shows a set of probit equations to explain the choice of Rights issues versus a Public offering method by a bank. Columns (1), (3), (5) and (7) report results for the whole sample period (2006-2016). Columns (2), (4), (6) and (8) show results for the crisis years (2007-2012). The dependent variable is the dummy Rights. Institutional Ownership is the percentage of shares outstanding owned by institutional investors. Market Volatility is defined as the volatility of daily returns on the Stoxx Europe Banks Index over the period $[-261 ;-1]$ with respect to the announcement date of the new issue. Stock Volatility is the volatility of the issuer's daily stock returns over the period [-261;-1] with respect to the announcement date of the new issue. Stock Run-Up is the return on the stock of the issuer over the period [$61 ;-1]$ with respect to the announcement date of the new issue. Turnover is the average number of shares traded daily in the period [-61;-1] with respect to the announcement date over the number of shares outstanding. Relative Size is the market value of the shares scaled by the book value of the issuer's total assets. Bank Size is measured as the natural logarithm of the issuer's total assets. Equity is calculated as the ratio of the book value of total equity over the book value of total assets. Aided Bank is a dummy that takes a value of 1 if the bank issuer receives State aid in the same year of the SEO, and 0 otherwise. State Ownership is the percentage of shares outstanding owned by State. $\triangle G D P p c$ is the annual growth rate of the Gross Domestic Product per capita in the country where the issuer is domiciled. T-statistics are in parentheses. ***, ** and * indicate levels of significance of $1 \%, 5 \%$, and $10 \%$, respectively.

\begin{tabular}{|c|c|c|c|c|c|c|c|c|}
\hline & $\begin{array}{l}\text { All sample } \\
\text { period } \\
(2006-2016)\end{array}$ & $\begin{array}{l}\text { Crisis years } \\
(2007-2012)\end{array}$ & $\begin{array}{l}\text { All sample } \\
\text { period } \\
(2006-2016)\end{array}$ & $\begin{array}{l}\text { Crisis years } \\
(2007-2012)\end{array}$ & $\begin{array}{l}\text { All sample } \\
\text { period } \\
(2006-2016)\end{array}$ & $\begin{array}{l}\text { Crisis years } \\
(2007-2012)\end{array}$ & $\begin{array}{l}\text { All sample } \\
\text { period } \\
(2006-2016)\end{array}$ & $\begin{array}{l}\text { Crisis year } \\
(2007-2012)\end{array}$ \\
\hline Dependent variable: Rights & (1) & (2) & (3) & (4) & (5) & (6) & (7) & (8) \\
\hline Institutional Ownership & $\begin{array}{c}0.0056 \\
(1.04)\end{array}$ & $\begin{array}{c}0.0268 * * \\
(2.53)\end{array}$ & $\begin{array}{l}0.0051 \\
(0.91)\end{array}$ & $\begin{array}{c}0.0252 * * \\
(2.37)\end{array}$ & $\begin{array}{c}0.0053 \\
(0.95)\end{array}$ & $\begin{array}{c}0.0252 * * \\
(2.36)\end{array}$ & $\begin{array}{l}0.0056 \\
(0.98)\end{array}$ & $\begin{array}{c}0.0268 * * \\
(2.48)\end{array}$ \\
\hline Market Volatility & $\begin{array}{c}0.0214^{*} \\
(1.83)\end{array}$ & $\begin{array}{c}0.0146 \\
(0.88)\end{array}$ & $\begin{array}{c}0.0194 \\
(1.63)\end{array}$ & $\begin{array}{c}0.0251 \\
(1.33)\end{array}$ & $\begin{array}{c}0.0172 \\
(1.34)\end{array}$ & $\begin{array}{c}0.0249 \\
(1.27)\end{array}$ & $\begin{array}{l}0.0171 \\
(1.33)\end{array}$ & $\begin{array}{l}0.0256 \\
(1.27)\end{array}$ \\
\hline Stock Volatility & $\begin{array}{c}-0.0042 \\
(-0.86)\end{array}$ & $\begin{array}{c}-0.0018 \\
(-0.31)\end{array}$ & $\begin{array}{c}-0.0046 \\
(-0.92)\end{array}$ & $\begin{array}{c}-0.0043 \\
(-0.70)\end{array}$ & $\begin{array}{c}-0.0036 \\
(-0.64)\end{array}$ & $\begin{array}{c}-0.0042 \\
(-0.62)\end{array}$ & $\begin{array}{c}-0.0034 \\
(-0.61)\end{array}$ & $\begin{array}{l}-0.0021 \\
(-0.30)\end{array}$ \\
\hline Stock Run Up & $\begin{array}{c}-0.0040 \\
(-0.82)\end{array}$ & $\begin{array}{c}-0.0053 \\
(-0.88)\end{array}$ & $\begin{array}{c}-0.0048 \\
(-0.95)\end{array}$ & $\begin{array}{c}-0.0061 \\
(-0.99)\end{array}$ & $\begin{array}{c}-0.0048 \\
(-0.96)\end{array}$ & $\begin{array}{c}-0.0061 \\
(-0.98)\end{array}$ & $\begin{array}{c}-0.0055 \\
(-1.08)\end{array}$ & $\begin{array}{l}-0.0105 \\
(-1.50)\end{array}$ \\
\hline Turnover & $\begin{array}{l}0.0773 \\
(0.75)\end{array}$ & $\begin{array}{l}0.2173 \\
(1.28)\end{array}$ & $\begin{array}{l}0.1487 \\
(1.42)\end{array}$ & $\begin{array}{c}0.1608 \\
(0.87)\end{array}$ & $\begin{array}{c}0.1378 \\
(1.30)\end{array}$ & $\begin{array}{c}0.1602 \\
(0.86)\end{array}$ & $\begin{array}{l}0.1216 \\
(1.17)\end{array}$ & $\begin{array}{l}0.1176 \\
(0.62)\end{array}$ \\
\hline Relative Size & $\begin{array}{c}0.3372 * * * \\
(2.75)\end{array}$ & $\begin{array}{c}2.2393 * * * \\
(4.01)\end{array}$ & $\begin{array}{c}0.1645 \\
(1.10)\end{array}$ & $\begin{array}{c}2.2684 * * * * \\
(3.36)\end{array}$ & $\begin{array}{r}0.1647 \\
(1.10)\end{array}$ & $\begin{array}{c}2.2663 * * * \\
(3.34)\end{array}$ & $\begin{array}{c}0.1628 \\
(1.08)\end{array}$ & $\begin{array}{c}2.6968 * * * \\
(3.54)\end{array}$ \\
\hline Bank Size & & & $\begin{array}{c}-0.1732 * * \\
(-2.55)\end{array}$ & $\begin{array}{c}-0.0869 \\
(-0.74)\end{array}$ & $\begin{array}{c}-0.1649 * * \\
(-2.34)\end{array}$ & $\begin{array}{c}-0.0870 \\
(-0.74)\end{array}$ & $\begin{array}{c}-0.1500 * * \\
(-2.09)\end{array}$ & $\begin{array}{l}-0.0401 \\
(-0.32)\end{array}$ \\
\hline Equity & & & $\begin{array}{r}-0.0247 \\
(-1.47)\end{array}$ & $\begin{array}{r}-0.1307 \\
(-1.33)\end{array}$ & $\begin{array}{c}-0.0235 \\
(-1.37)\end{array}$ & $\begin{array}{c}-0.1310 \\
(-1.33)\end{array}$ & $\begin{array}{c}-0.0212 \\
(-1.21)\end{array}$ & $\begin{array}{l}-0.1306 \\
(-1.29)\end{array}$ \\
\hline Aided Bank & & & & & $\begin{array}{c}-0.1726 \\
(-0.45)\end{array}$ & $\begin{array}{c}-0.0226 \\
(-0.04)\end{array}$ & $\begin{array}{c}-0.0071 \\
(-0.02)\end{array}$ & $\begin{array}{c}0.2310 \\
(0.39)\end{array}$ \\
\hline State Ownership & & & & & & & $\begin{array}{c}-0.0096 \\
(-1.02)\end{array}$ & $\begin{array}{c}-0.0288^{*} \\
(-1.78)\end{array}$ \\
\hline$\triangle G D P p c$ & $\begin{array}{c}0.0075 \\
(0.16)\end{array}$ & $\begin{array}{c}0.0389 \\
(0.65)\end{array}$ & $\begin{array}{c}-0.0158 \\
(-0.31)\end{array}$ & $\begin{array}{c}0.0653 \\
(0.95)\end{array}$ & $\begin{array}{c}-0.0222 \\
(-0.42)\end{array}$ & $\begin{array}{c}0.0644 \\
(0.25)\end{array}$ & $\begin{array}{l}-0.0157 \\
-(0.30)\end{array}$ & $\begin{array}{l}0.0767 \\
(1.05)\end{array}$ \\
\hline$R$-Squared & 0.0949 & 0.3342 & 0.1480 & 0.3509 & 0.1493 & 0.3509 & 0.1561 & 0.3809 \\
\hline \# Observations & 124 & 96 & 124 & 96 & 124 & 96 & 124 & 96 \\
\hline
\end{tabular}


Table 5: The determinants of the announcement effect for bank SEOs

This table shows the announcement effects of a bank's rights issue decision. Columns (1), (3), (5) and (7) report results for the whole sample period (2006-2016). Columns (2), (4), (6) and (8) show results for the crisis years (2007-2012). The dependent variable (ARl) is the announcement-day abnormal returns over the Stoxx Europe Bank Index. Market Volatility is defined as the volatility of daily returns on the Stoxx Europe Banks Index over the period [-261; -1] with respect to the announcement date of the new issue. Stock Volatility is the volatility of the issuer's daily stock returns over the period [-261;-1] with respect to the announcement date of the new issue. Stock Run-Up is the return on the stock of the issuer over the period [-61;-1] with respect to the announcement date of the new issue. Turnover is the average number of shares traded daily in the period [-61;-1] with respect to the announcement date over the number of shares outstanding. Relative Size is the market value of the shares scaled by the book value of the issuer's total assets. Bank Size is measured as the natural logarithm of the issuer's total assets. Equity is calculated as the ratio of the book value of total equity over the book value of total assets. Aided Bank is a dummy that takes a value of 1 if the bank issuer receives State aid in the same year of the SEO, and 0 otherwise. State Ownership is the percentage of shares outstanding owned by State. $\triangle G D P p c$ is the annual growth rate of the Gross Domestic Product per capita in the country where the issuer is domiciled. T-statistics are in parentheses. ***,** and * indicate levels of significance of $1 \%, 5 \%$, and $10 \%$, respectively.

\begin{tabular}{|c|c|c|c|c|c|c|c|c|}
\hline & $\begin{array}{l}\text { All sample } \\
\text { period } \\
(2006-2016)\end{array}$ & $\begin{array}{l}\text { Crisis years } \\
(2007-2012)\end{array}$ & $\begin{array}{l}\text { All sample } \\
\text { period } \\
(2006-2016)\end{array}$ & $\begin{array}{l}\text { Crisis years } \\
(\mathbf{2 0 0 7 - 2 0 1 2 )}\end{array}$ & $\begin{array}{l}\text { All sample } \\
\text { period } \\
(2006-2016)\end{array}$ & $\begin{array}{l}\text { Crisis years } \\
(2007-2012)\end{array}$ & $\begin{array}{l}\text { All sample } \\
\text { period } \\
(2006-2016)\end{array}$ & $\begin{array}{l}\text { Crisis years } \\
(2007-2012)\end{array}$ \\
\hline Dependent variable: $A R 1$ & (1) & (2) & (3) & (4) & (5) & (6) & (7) & (8) \\
\hline Rights & $\begin{array}{l}-2.4720 \\
(-1.43)\end{array}$ & $\begin{array}{c}-5.2016^{* * *} \\
(-2.19)\end{array}$ & $\begin{array}{c}-2.5619 \\
(-1.46)\end{array}$ & $\begin{array}{c}-5.8187 * * \\
(-2.41)\end{array}$ & $\begin{array}{r}-2.3979 \\
(-1.37)\end{array}$ & $\begin{array}{c}-5.4729^{* *} \\
(-2.30)\end{array}$ & $\begin{array}{l}-2.2335 \\
(-1.27)\end{array}$ & $\begin{array}{c}-5.1352 * * \\
(-2.21)\end{array}$ \\
\hline Market Volatility & $\begin{array}{c}0.0309 \\
(0.38)\end{array}$ & $\begin{array}{l}0.1131 \\
(1.01)\end{array}$ & $\begin{array}{l}0.0350 \\
(0.43)\end{array}$ & $\begin{array}{l}0.1392 \\
(1.23)\end{array}$ & $\begin{array}{l}-0.0265 \\
(-0.29)\end{array}$ & $\begin{array}{l}0.0413 \\
(0.34)\end{array}$ & $\begin{array}{c}-0.0302 \\
(-0.33)\end{array}$ & $\begin{array}{l}0.0293 \\
(0.24)\end{array}$ \\
\hline Stock Volatility & $\begin{array}{c}-0.0130 \\
(-0.38)\end{array}$ & $\begin{array}{c}-0.0202 \\
(-0.48)\end{array}$ & $\begin{array}{c}-0.0113 \\
(-0.32)\end{array}$ & $\begin{array}{c}-0.0162 \\
(-0.38)\end{array}$ & $\begin{array}{c}0.0142 \\
(0.37)\end{array}$ & $\begin{array}{c}0.0292 \\
(0.60)\end{array}$ & $\begin{array}{l}0.0110 \\
(0.29)\end{array}$ & $\begin{array}{c}0.0380 \\
(0.80)\end{array}$ \\
\hline Stock Run Up & $\begin{array}{c}0.0746^{* * * *} \\
(2.89)\end{array}$ & $\begin{array}{c}0.0687 * * \\
(2.21)\end{array}$ & $\begin{array}{c}0.0707 * * * \\
(2.68)\end{array}$ & $\begin{array}{c}0.0628^{*} \\
(1.97)\end{array}$ & $\begin{array}{c}0.0705^{* * * *} \\
(2.69)\end{array}$ & $\begin{array}{c}0.0584 \\
(1.86)\end{array}$ & $\begin{array}{c}0.0702^{* * * *} \\
(2.67)\end{array}$ & $\begin{array}{c}0.0475 \\
(1.53)\end{array}$ \\
\hline Turnover & $\begin{array}{l}-0.6336 \\
(-1.54)\end{array}$ & $\begin{array}{c}-0.7142 \\
(-1.11)\end{array}$ & $\begin{array}{c}-0.5836 \\
(-1.33)\end{array}$ & $\begin{array}{l}-0.4623 \\
(-0.70)\end{array}$ & $\begin{array}{l}-0.6913 \\
(-1.57)\end{array}$ & $\begin{array}{c}-0.6233 \\
(-0.95)\end{array}$ & $\begin{array}{c}-0.7420 \\
(-1.66)\end{array}$ & $\begin{array}{l}-0.8159 \\
(-1.26)\end{array}$ \\
\hline Relative Size & $\begin{array}{c}0.4972 \\
(0.80)\end{array}$ & $\begin{array}{c}2.8336^{*} \\
(1.73)\end{array}$ & $\begin{array}{c}-0.0684 \\
(-0.08)\end{array}$ & $\begin{array}{l}2.8184 \\
(1.64)\end{array}$ & $\begin{array}{c}-0.2933 \\
(-0.32)\end{array}$ & $\begin{array}{l}2.3204 \\
(1.36)\end{array}$ & $\begin{array}{c}-0.3631 \\
(-0.39)\end{array}$ & $\begin{array}{l}1.9652 \\
(1.17)\end{array}$ \\
\hline Bank Size & & & $\begin{array}{c}-0.2883 \\
(-0.63)\end{array}$ & $\begin{array}{c}-0.5340 \\
(-0.80)\end{array}$ & $\begin{array}{l}-0.1246 \\
(-0.27)\end{array}$ & $\begin{array}{l}-0.3948 \\
(-0.60)\end{array}$ & $\begin{array}{c}-0.0826 \\
(-0.18)\end{array}$ & $\begin{array}{c}-0.2274 \\
(-0.35)\end{array}$ \\
\hline Equity & & & $\begin{array}{l}0.0374 \\
(0.47)\end{array}$ & $\begin{array}{l}0.6546 \\
(1.04)\end{array}$ & $\begin{array}{l}0.0655 \\
(0.80)\end{array}$ & $\begin{array}{l}0.4765 \\
(0.76)\end{array}$ & $\begin{array}{l}0.0773 \\
(0.93)\end{array}$ & $\begin{array}{l}0.5445 \\
(0.89)\end{array}$ \\
\hline Aided Bank & & & & & $\begin{array}{r}-3.7429 \\
(-1.59)\end{array}$ & $\begin{array}{c}-6.0469^{*} \\
(-1.84)\end{array}$ & $\begin{array}{l}-2.9400 \\
(-1.15)\end{array}$ & $\begin{array}{l}-5.1446 \\
(-1.59)\end{array}$ \\
\hline State Ownership & & & & & & & $\begin{array}{c}-0.0472 \\
(-0.84)\end{array}$ & $\begin{array}{c}-0.1596 * * \\
(-2.07)\end{array}$ \\
\hline$\triangle G D P p c$ & $\begin{array}{l}0.3458 \\
(0.94)\end{array}$ & $\begin{array}{l}0.7094 \\
(1.55)\end{array}$ & $\begin{array}{l}0.3712 \\
(0.99)\end{array}$ & $\begin{array}{c}0.8010^{*} \\
(1.72)\end{array}$ & $\begin{array}{l}0.1772 \\
(0.45)\end{array}$ & $\begin{array}{l}0.4611 \\
(0.94)\end{array}$ & $\begin{array}{l}0.1879 \\
(0.48)\end{array}$ & $\begin{array}{l}0.4209 \\
(0.87)\end{array}$ \\
\hline Country Fixed Effects & Yes & Yes & Yes & Yes & Yes & Yes & Yes & Yes \\
\hline$R$-Squared & 0.2520 & 0.3003 & 0.2577 & 0.3284 & 0.2772 & 0.3613 & 0.2826 & 0.4008 \\
\hline \# Observations & 124 & 96 & 124 & 96 & 124 & 96 & 124 & 96 \\
\hline
\end{tabular}


Table 6: The announcement effects of banks' rights issues during crisis: relative offering size and bank characteristics

This table shows whether the announcement effects of a bank's rights issue decision vary across banks depending on the relative offering size, bank size, and bank capital level. Columns (1), (3) and (5) report results for subsamples in which the variables Relative Size, Bank size and Equity are respectively above their median value in the sample. Columns (2), (4) and (6) report results for subsamples in which the variables Relative Size, Bank size and Equity are respectively below their median value in the sample. The dependent variable $(A R I)$ is the announcement-day abnormal returns over the Stoxx Europe Bank Index. Rights is as dummy variable that takes the value of 1 for rights issues and 0 otherwise. Market Volatility is defined as the volatility of daily returns on the Stoxx Europe Banks Index over the period $[-261 ;-1]$ with respect to the announcement date of the new issue. Stock Volatility is the volatility of the issuer's daily stock returns over the period [-261;-1] with respect to the announcement date of the new issue. Stock Run-Up is the return on the stock of the issuer over the period $[-61 ;-1]$ with respect to the announcement date of the new issue. Turnover is the average number of shares traded daily in the period [-61;-1] with respect to the announcement date over the number of shares outstanding. Relative Size is the market value of the shares scaled by the book value of the issuer's total assets. Bank Size is measured as the natural logarithm of the issuer's total assets. Equity is calculated as the ratio of the book value of total equity over the book value of total assets. $\triangle G D P p c$ is the annual growth rate of the Gross Domestic Product per capita in the country where the issuer is domiciled. T-statistics are in parentheses. ***, ** and * indicate levels of significance of $1 \%, 5 \%$, and $10 \%$, respectively. We test whether the difference between the coefficients of Rights across subsamples above and below the median is significant. The statistic corresponding to this test is reported at the end of the Table.

\begin{tabular}{lcccccc}
\hline \hline & \multicolumn{2}{c}{ Relative Size } & \multicolumn{2}{c}{ Bank Size } & \multicolumn{2}{c}{ Equity } \\
\hline \hline & Above & Below & Above & Below & Above & Below \\
\hline Dependent variable: ARI & $(1)$ & $(2)$ & $(3)$ & $(4)$ & $(5)$ & $(6)$ \\
\hline \multirow{2}{*}{ Rights } & 6.3256 & $-12.2113^{*}$ & $-14.0826^{* * *}$ & -1.9609 & -0.6916 & $-12.5941^{* * *}$ \\
& $(1.24)$ & $(-2.56)$ & $(-2.78)$ & $(-0.76)$ & $(-0.30)$ & $(-2.82)$ \\
\hline \multirow{2}{*}{ Market Volatility } & -0.1221 & 0.3222 & 0.2392 & 0.1889 & 0.0955 & 0.3424 \\
& $(-0.79)$ & $(1.44)$ & $(0.92)$ & $(1.61)$ & $(0.96)$ & $(1.31)$ \\
Stock Volatility & 0.0854 & -0.1624 & -0.1302 & 0.0078 & 0.0441 & -0.1311 \\
& $(1.67)$ & $(-1.67)$ & $(-1.31)$ & $(0.13)$ & $(1.05)$ & $(-1.49)$ \\
Stock Run Up & $0.0782^{* *}$ & 0.0518 & 0.0618 & 0.0155 & 0.0416 & 0.0716 \\
& $(2.01)$ & $(0.89)$ & $(1.19)$ & $(0.35)$ & $(1.01)$ & $(1.31)$ \\
Turnover & -0.4680 & -2.3908 & 0.0487 & -0.9039 & -0.7369 & 0.4613 \\
& $(-0.77)$ & $(-1.09)$ & $(0.03)$ & $(-1.33)$ & $(-1.38)$ & $(0.03)$ \\
Relative Size & 0.0488 & -4.3708 & $10.8243 *$ & 1.2971 & -0.0405 & $8.1432^{* *}$ \\
& $(0.03)$ & $(-0.25)$ & $(1.97)$ & $(0.90)$ & $(-0.03)$ & $(2.24)$ \\
Bank Size & 0.2751 & -2.1379 & -2.0632 & -0.8601 & $-1.4013 *$ & -0.5286 \\
& $(0.37)$ & $(-1.05)$ & $(-0.76)$ & $(-0.97)$ & $(-1.85)$ & $(-0.41)$ \\
Equity & 0.8327 & -2.1264 & -1.7798 & $1.0468 *$ & 0.8144 & -0.8371 \\
& $(1.23)$ & $(-0.94)$ & $(-0.79)$ & $(1.80)$ & $(1.55)$ & $(-0.40)$ \\
SGDPpc & -0.5896 & 1.2873 & 0.9346 & $0.9928 * *$ & $1.0162^{*}$ & 1.0856 \\
& $(-0.91)$ & $(1.29)$ & $(0.86)$ & $(2.19)$ & $(2.03)$ & $(1.14)$ \\
\hline Country Fixed Effects & Yes & Yes & Yes & Yes & Yes & Yes \\
\hline R-Squared & 0.5585 & 0.5076 & 0.4240 & 0.4946 & 0.5193 & 0.5461 \\
\# Observations & 48 & 48 & 46 & 50 & 48 & 48 \\
Test for Rights & & & $21.84 * * *$ & & $7.12^{* * *}$ \\
\hline
\end{tabular}


Table 7: The announcement effect of banks' rights issues during crisis: institutional quality and banking market characteristics

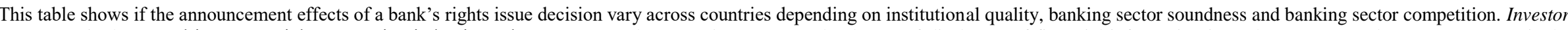

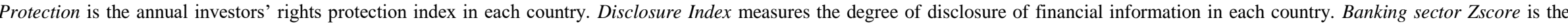

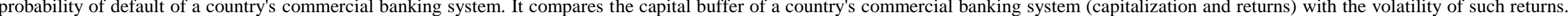

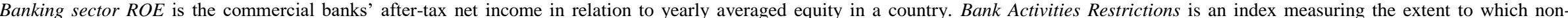

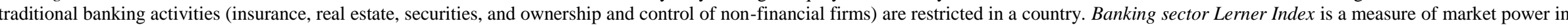

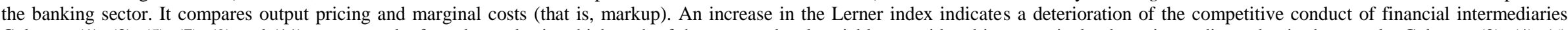

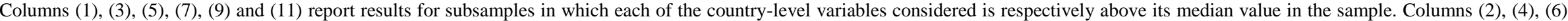

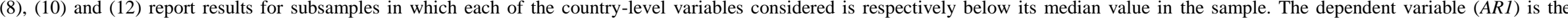

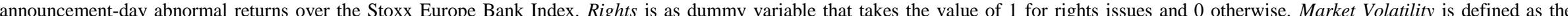

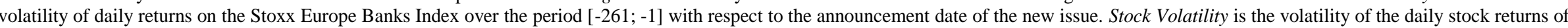

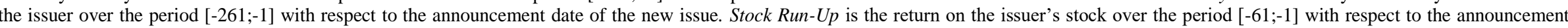

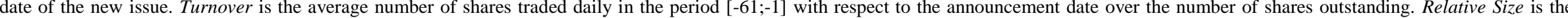

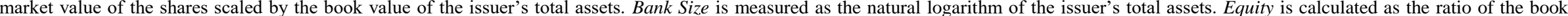

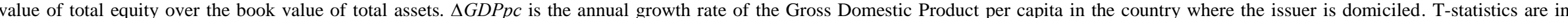

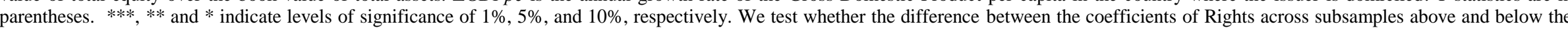
median is significant. The statistic corresponding to this test is reported at the end of the Table.

\begin{tabular}{|c|c|c|c|c|c|c|c|c|c|c|c|c|}
\hline & \multicolumn{4}{|c|}{ Institutional Quality } & \multicolumn{4}{|c|}{ "Banking Sector Soundness } & \multicolumn{4}{|c|}{ " Banking Sector Competition } \\
\hline & \multicolumn{2}{|c|}{$\begin{array}{l}\text { Investor } \\
\text { Protection }\end{array}$} & \multicolumn{2}{|c|}{$\begin{array}{l}\text { Disclosure } \\
\text { Index }\end{array}$} & \multicolumn{2}{|c|}{$\begin{array}{c}\text { Banking Sector } \\
\text { Z-score }\end{array}$} & \multicolumn{2}{|c|}{$\begin{array}{c}\text { Banking Sector } \\
\text { ROE }\end{array}$} & \multicolumn{2}{|c|}{$\begin{array}{c}\text { Bank Activities } \\
\text { Restrictions }\end{array}$} & \multicolumn{2}{|c|}{$\begin{array}{l}\text { Banking Sector } \\
\text { Lerner Index }\end{array}$} \\
\hline & Above & Below & Above & Below & Above & Below & Above & Below & Above & Below & Above & Below \\
\hline Dependent variable: AR1 & $(1)$ & $(2)$ & (3) & (4) & $(5)$ & $(6)$ & $(7)$ & $(8)$ & (9) & $(10)$ & $(11)$ & $(12)$ \\
\hline Rights & $\begin{array}{c}-11.5418^{*} \\
(-1.77)\end{array}$ & $\begin{array}{c}-1.8944 \\
(-0.96)\end{array}$ & $\begin{array}{c}-12.2790 * \\
(-1.82)\end{array}$ & $\begin{array}{r}-1.9277 \\
(-0.89) \\
\end{array}$ & $\begin{array}{r}-0.5149 \\
(-0.22) \\
\end{array}$ & $\begin{array}{c}-10.2765^{* *} \\
(-2.18)\end{array}$ & $\begin{array}{r}-2.3753 \\
(-0.81) \\
\end{array}$ & $\begin{array}{c}-10.8824 * * * * \\
(-2.84)\end{array}$ & $\begin{array}{c}-0.5366 \\
(-0.17) \\
\end{array}$ & $\begin{array}{c}-10.8833 * * * \\
(-2.82)\end{array}$ & $\begin{array}{c}-0.3583 \\
(-0.14) \\
\end{array}$ & $\begin{array}{c}-12.7552 * * \\
(-2.56)\end{array}$ \\
\hline Market Volatility & $\begin{array}{r}-0.1359 \\
(-0.34)\end{array}$ & $\begin{array}{c}0.1782 * * \\
(2.16)\end{array}$ & $\begin{array}{c}0.2423 \\
(0.65)\end{array}$ & $\begin{array}{l}0.1217 \\
(1.24)\end{array}$ & $\begin{array}{c}0.2720^{* *} \\
(2.27)\end{array}$ & $\begin{array}{l}0.2682 \\
(1.01)\end{array}$ & $\begin{array}{c}0.0548 \\
(0.45)\end{array}$ & $\begin{array}{l}0.2589 \\
(1.12)\end{array}$ & $\begin{array}{l}0.0151 \\
(0.11)\end{array}$ & $\begin{array}{l}0.2252 \\
(1.09)\end{array}$ & $\begin{array}{l}-0.1407 \\
(-1.11)\end{array}$ & $\begin{array}{r}0.3277 \\
(1.43)\end{array}$ \\
\hline Stock Volatility & $\begin{array}{c}-0.0032 \\
(-0.03)\end{array}$ & $\begin{array}{c}-0.0550 \\
(-1.13)\end{array}$ & $\begin{array}{c}-0.1517 \\
(-0.99)\end{array}$ & $\begin{array}{l}0.0046 \\
(0.11)\end{array}$ & $\begin{array}{c}0.0151 \\
(0.38)\end{array}$ & $\begin{array}{c}-0.0876 \\
(-0.95)\end{array}$ & $\begin{array}{c}0.0874 \\
(1.30)\end{array}$ & $\begin{array}{l}-0.0915 \\
(-1.26)\end{array}$ & $\begin{array}{c}0.0527 \\
(1.00)\end{array}$ & $\begin{array}{c}-0.1013 \\
(-1.51)\end{array}$ & $\begin{array}{c}0.0213 \\
(0.35)\end{array}$ & $\begin{array}{c}-0.0669 \\
(-0.96)\end{array}$ \\
\hline Stock Run Up & $\begin{array}{c}0.1036 \\
(1.13)\end{array}$ & $\begin{array}{c}0.0339 \\
(1.25)\end{array}$ & $\begin{array}{c}0.0295 \\
(0.35)\end{array}$ & $\begin{array}{l}0.0512 \\
(1.59)\end{array}$ & $\begin{array}{c}0.1540 * * * \\
(3.39)\end{array}$ & $\begin{array}{l}0.0445 \\
(0.85)\end{array}$ & $\begin{array}{r}0.0207 \\
(0.46)\end{array}$ & $\begin{array}{c}0.0826 \\
(1.54)\end{array}$ & $\begin{array}{l}0.0170 \\
(0.43)\end{array}$ & $\begin{array}{c}0.0876^{*} \\
(1.75)\end{array}$ & $\begin{array}{c}0.0721^{*} \\
(1.83)\end{array}$ & $\begin{array}{c}0.0475 \\
(0.68)\end{array}$ \\
\hline Turnover & $\begin{array}{r}-0.5647 \\
(-0.15)\end{array}$ & $\begin{array}{c}-0.4353 \\
(-0.99)\end{array}$ & $\begin{array}{c}-2.8459 \\
(-0.80)\end{array}$ & $\begin{array}{c}-0.5603 \\
(-1.09)\end{array}$ & $\begin{array}{r}-0.1372 \\
(-0.24)\end{array}$ & $\begin{array}{l}0.0514 \\
(0.03)\end{array}$ & $\begin{array}{c}0.2713 \\
(0.22)\end{array}$ & $\begin{array}{r}-1.0887 \\
(-0.85)\end{array}$ & $\begin{array}{c}-0.3432 \\
(-0.66)\end{array}$ & $\begin{array}{r}-1.5413 \\
(-0.87)\end{array}$ & $\begin{array}{l}0.9836 \\
(1.06)\end{array}$ & $\begin{array}{c}-1.6214 \\
(-1.65)\end{array}$ \\
\hline Relative Size & $\begin{array}{r}3.6727 \\
(0.68)\end{array}$ & $\begin{array}{l}2.3563 \\
(1.61)\end{array}$ & $\begin{array}{l}1.9802 \\
(0.41)\end{array}$ & $\begin{array}{l}1.9747 \\
(1.16)\end{array}$ & $\begin{array}{r}-2.7150 \\
(-0.83)\end{array}$ & $\begin{array}{l}3.8809 \\
(1.43)\end{array}$ & $\begin{array}{r}-0.0471 \\
(-0.03)\end{array}$ & $\begin{array}{c}8.4816^{* * *} \\
(2.46)\end{array}$ & $\begin{array}{c}-0.1684 \\
(-0.08)\end{array}$ & $\begin{array}{c}10.4883 * * \\
(2.41)\end{array}$ & $\begin{array}{l}0.0766 \\
(0.03)\end{array}$ & $\begin{array}{c}11.4453 * * \\
(2.52)\end{array}$ \\
\hline Bank Size & $\begin{array}{r}-1.3304 \\
(-0.37)\end{array}$ & $\begin{array}{l}0.0931 \\
(0.19)\end{array}$ & $\begin{array}{c}-3.9123 \\
(-0.91)\end{array}$ & $\begin{array}{c}-0.0860 \\
(-0.16)\end{array}$ & $\begin{array}{r}-0.4645 \\
(-0.72)\end{array}$ & $\begin{array}{c}-2.0764 \\
(-0.77)\end{array}$ & $\begin{array}{c}-0.9745 \\
(-1.25)\end{array}$ & $\begin{array}{c}-0.5309 \\
(-0.37)\end{array}$ & $\begin{array}{c}-0.4223 \\
(-0.60)\end{array}$ & $\begin{array}{c}-1.5413 \\
(-0.87)\end{array}$ & $\begin{array}{c}-0.8438 \\
(-0.98)\end{array}$ & $\begin{array}{c}-0.1239 \\
(-0.10)\end{array}$ \\
\hline Equity & $\begin{array}{l}1.2528 \\
(0.29)\end{array}$ & $\begin{array}{c}0.5770 \\
(1.31)\end{array}$ & $\begin{array}{c}-3.7354 \\
(-0.82)\end{array}$ & $\begin{array}{c}0.8574 * \\
(1.77)\end{array}$ & $\begin{array}{c}1.3992 * * \\
(2.03)\end{array}$ & $\begin{array}{c}-0.1663 \\
(-0.13)\end{array}$ & $\begin{array}{c}0.2284 \\
(0.41)\end{array}$ & $\begin{array}{c}-0.1684 \\
(-0.09)\end{array}$ & $\begin{array}{c}0.4944 \\
(0.88)\end{array}$ & $\begin{array}{c}1.0488 * * \\
(2.41)\end{array}$ & $\begin{array}{c}0.3509 \\
(0.56)\end{array}$ & $\begin{array}{c}0.6202 \\
(0.44)\end{array}$ \\
\hline$\triangle G D P p c$ & $\begin{array}{c}-0.0032 \\
(-0.00) \\
\end{array}$ & $\begin{array}{c}0.5942 * \\
(1.75) \\
\end{array}$ & $\begin{array}{l}1.6768 \\
(1.18) \\
\end{array}$ & $\begin{array}{c}0.5110 \\
(1.19) \\
\end{array}$ & $\begin{array}{c}1.4121 * * \\
(2.43)\end{array}$ & $\begin{array}{c}0.6306 \\
(0.75) \\
\end{array}$ & $\begin{array}{c}0.5366 \\
(1.13) \\
\end{array}$ & $\begin{array}{l}1.7966 \\
(1.54) \\
\end{array}$ & $\begin{array}{c}-0.1511 \\
(-0.25) \\
\end{array}$ & $\begin{array}{c}1.6426^{*} \\
(1.87) \\
\end{array}$ & $\begin{array}{c}-0.9406 \\
(-1.38) \\
\end{array}$ & $\begin{array}{c}2.1855^{*} \\
(2.06) \\
\end{array}$ \\
\hline Country Fixed Effects & Yes & Yes & Yes & Yes & Yes & Yes & Yes & Yes & Yes & Yes & Yes & Yes \\
\hline$R$-Squared & 0.3622 & 0.4475 & 0.4386 & 0.3910 & 0.6433 & 0.3064 & 0.4959 & 0.4844 & 0.4454 & 0.4997 & 0.4725 & 0.5539 \\
\hline \# Observations & 32 & 64 & 30 & 66 & 48 & 48 & 47 & 49 & 44 & 52 & 45 & 47 \\
\hline Test for Rights & \multicolumn{2}{|c|}{$24.07 * * *$} & \multicolumn{2}{|c|}{$22.86^{* * * *}$} & \multicolumn{2}{|c|}{$4.30 * *$} & \multicolumn{2}{|c|}{$4.92 * *$} & \multicolumn{2}{|c|}{$7.20 * *$} & \multicolumn{2}{|c|}{$6.21 * *$} \\
\hline
\end{tabular}




\section{ONLINE APPENDIX}

\section{Table A.1: State aid by bank}

This table shows the list of banks that received State aid during our sample period, the specific type of State aid they received and the corresponding amount. Information about the State ownership prior to the State Aid is also provided. Notes: a) For Crédit Agricole and Erste Group Bank, state ownership is below 3\% and indirect, via domestic and foreign governments' sovereign funds; b) IKB's main shareholder, KfW, is a German development bank, owned by the federal government $(80 \%)$ and the German regional states (20\%) c) €3.5 billion is Germany's estimate of total expected losses from the risk shields granted to IBK, which totaled about $€ 9$ billion; and d) Previously, General Bank of Greece. In December 2012 all shares were sold to Piraeus Bank.

\begin{tabular}{|c|c|c|c|c|c|}
\hline Bank & Country & Date & Type of state aid & Amount & State owned \\
\hline Banco BPI & Portugal & 2012 & Recapitalization (hybrid securities) & $€ 1.5 \mathrm{bn}$. & No \\
\hline Banco Comercial Portugues & Portugal & 2012 & Recapitalization (hybrid securities) & $€ 3.0$ bn. & Yes \\
\hline \multirow[t]{3}{*}{ Bank of Ireland } & Ireland & 2009 & Recapitalization (participation in capital) & $€ 3.5 \mathrm{bn}$. & Yes \\
\hline & & 2010 & Recapitalization (participation in capital) & $€ 0.2 \mathrm{bn}$ & \\
\hline & & 2011 & Recapitalization (hybrid securities) & $€ 1.0 \mathrm{bn}$ & \\
\hline Crédit Agricole & France & 2008 & Recapitalization (subordinated loans) & $€ 3.0 \mathrm{bn}$. & Yes $^{\mathrm{a}}$ \\
\hline Erste Group Bank & Austria & 2009 & Recapitalization (participation in capital) & $€ 1.22$ bn. & Yes $^{\mathrm{a}}$ \\
\hline Piraeus Bank & Greece & 2011 & Recapitalization (participation in capital) & $€ 5$ bn. & No \\
\hline \multirow[t]{3}{*}{ IKB Deutsche Industriebank } & Germany & 2007 & Government Guarantees & $€ 3.5 \mathrm{bn}^{\mathrm{c}}$ & $\mathrm{No}^{\mathrm{b}}$ \\
\hline & & 2008 & Recapitalization (participation in capital) & $€ 2.3 \mathrm{bn}$ & \\
\hline & & 2008 & Liquidity facilities & $€ 2.5 \mathrm{bn}$ & \\
\hline Lloyds Banking Group & United Kingdom & 2008 & Recapitalization (participation in capital) & $€ 19$ bn. & No \\
\hline Royal Bank of Scotland Group & United Kingdom & 2009 & Recapitalization (participation in capital) & $€ 22$ bn. & No \\
\hline
\end{tabular}




\section{Table A.2: Sample breakdown by State aid and State ownership}

This table shows the number of rights issues and public offers in our sample conditioning on SEOs being connected to State aid or State ownership, for the whole sample period and during the crisis. Banks that received State aid are listed in Table A.1. Banks with State ownership include: Erste Group Bank, Danske Bank, Jyske Bank, Crédit Agricole, Socièté Générale, BNP Paribas, Lloyds Banking Group, Royal Bank of Scotland Group, Standard Chartered, HSBC, Deutsche Bank, HSBC Trinkaus \& Burkhardt, TT Hellenic Postbank, Bank of Ireland, Bank Polska Kasa Opieki, Bank BPH, Bank Millenium, BRE Bank, Banco Comercial Portugues, Banco Sabadell, Nova Kreditna Banka Maribor, Nordea Bank, Skandinaviska Enskilda Banken, Swedbank.

All Crisis

(2006-2016)

(2007-2012)

\begin{tabular}{|c|c|c|c|c|c|c|c|}
\hline \multicolumn{2}{|c|}{ Rights Issues | Public Offers } & \multicolumn{3}{|c|}{ State Ownership } & \multicolumn{3}{|c|}{ State Ownership } \\
\hline & & Yes & No & Tot. & Yes & No & Tot. \\
\hline \multirow[t]{3}{*}{ State Aid } & Yes & $5 \mid 10$ & $7 \mid 2$ & $12 \mid 12$ & $4 \mid 4$ & $6 \mid 2$ & $10 \mid 6$ \\
\hline & No & $19 \mid 11$ & $51 \mid 19$ & $70 \mid 30$ & $19 \mid 10$ & $39 \mid 12$ & $58 \mid 22$ \\
\hline & Tot. & $24 \mid 21$ & $58 \mid 21$ & $82 \mid 42$ & $25 \mid 14$ & $45 \mid 14$ & $68 \mid 28$ \\
\hline
\end{tabular}


Table A.3: Robustness test, recurrent issuers only

This table shows the announcement effects of a bank's rights issue decision depending on whether the bank has used both offering methods or not. The sample includes only SEOs carried out during the crisis by banks that have carried out multiple SEOs. The dependent variable (AR1) is the announcement-day abnormal returns over the Stoxx Europe Bank Index. Rights is as dummy variable that takes the value of 1 for rights issues and 0 otherwise. Market Volatility is defined as the volatility of daily returns on the Stoxx Europe Banks Index over the period $[-261 ;-1]$ with respect to the announcement date of the new issue. Stock Volatility is the volatility of the issuer's daily stock returns over the period [$261 ;-1]$ with respect to the announcement date of the new issue. Stock Run-Up is the return on the issuer's stock over the period $[-61 ;-1]$ with respect to the announcement date of the new issue. Turnover is the average number of shares traded daily in the period [-61;-1] with respect to the announcement date over the number of shares outstanding. Relative Size is the market value of the shares scaled by the book value of the issuer's total assets. Bank Size is measured as the natural logarithm of the issuer's total assets. Equity is calculated as the ratio of the book value of total equity over the book value of total assets. $\triangle \mathrm{GDPpc}$ is the annual growth rate of the Gross Domestic Product per capita in the country where the issuer is domiciled. T-statistics are in parentheses. $* * *, * *$ and $*$ indicate levels of significance of $1 \%, 5 \%$, and $10 \%$, respectively.

\begin{tabular}{lcc}
\hline \hline & $\begin{array}{c}\text { Banks with more than one SEO but } \\
\text { same offering method }\end{array}$ & $\begin{array}{c}\text { Banks with more than one SEO and } \\
\text { both offering methods }\end{array}$ \\
\hline Dependent variable: ARI & $(\mathbf{1})$ & $\mathbf{( 2 )}$ \\
\hline Rights & 0.4701 & $-9.4524^{* *}$ \\
& $(-2.23)$ \\
Market Volatility & -0.1529 & 0.1140 \\
Stock Volatility & $(-1.09)$ & $(0.44)$ \\
& 0.2076 & -0.0910 \\
Stock Run Up & $(1.27)$ & $(-1.11)$ \\
& 0.0235 & 0.0687 \\
Turnover & $(0.71)$ & $(1.07)$ \\
Relative Size & -0.5935 & -1.2004 \\
& $(-1.11)$ & $(-0.53)$ \\
Bank Size & -0.4037 & $8.7172^{*}$ \\
& $(-0.20)$ & $(1.73)$ \\
Equity & -0.7202 & -0.7029 \\
SGDPpc & $(-0.27)$ & $(-0.36)$ \\
Country Fixed Effects & 1.2468 & -2.1575 \\
R-Squared & $(0.92)$ & $(-0.83)$ \\
\# Observations & 0.2396 & 1.8681 \\
Test for Rights & $(0.40)$ & $(1.39)$ \\
\hline \hline
\end{tabular}


Table A.4: Robustness test, endogeneity of the choice of the issuing method

This table shows the announcement effects of a bank's rights issue decision controlling by the potential endogeneity of the rights issue decision. Heckman's Lambda, or the inverse Mill's ratio, allows us to test the endogeneity of the choice of the issuing method. The proportion of the issuer's shares outstanding owned by institutional investors is used in the first stage as an instrumental variable to explain the rights issue decision and excluded from the second stage. Our assumption is that a higher or lower level of institutional ownership affects the decision to opt for a rights issue or a public offering but is not related to announcement day returns. In all specifications, the dependent variable (AR1) is the announcement-day abnormal returns over the Stoxx Europe Bank Index. Rights is as dummy variable that takes the value of 1 for rights issues and 0 otherwise. Market Volatility is defined as the volatility of daily returns on the Stoxx Europe Banks Index over the period $[-261 ;-1]$ with respect to the announcement date of the new issue. Stock Volatility is the volatility of the issuer's daily stock returns over the period $[-261 ;-1]$ with respect to the announcement date of the new issue. Stock Run-Up is the return on the issuer's stock over the period [-61;-1] with respect to the announcement date of the new issue. Turnover is the average number of shares traded daily in the period $[-61 ;-1]$ with respect to the announcement date over the number of shares outstanding. Relative Size is the market value of the shares scaled by the book value of the issuer's total assets. Bank Size is measured as the natural logarithm of the issuer's total assets. Equity is calculated as the ratio of the book value of total equity over the book value of total assets. $\triangle \mathrm{GDPpc}$ is the annual growth rate of the Gross Domestic Product per capita in the country where the issuer is domiciled. T-statistics are in parentheses. $* * *, * *$ and $*$ indicate levels of significance of $1 \%, 5 \%$, and $10 \%$, respectively.

\begin{tabular}{|c|c|c|}
\hline "Dependent variable:AR1 & (1) & (2) \\
\hline Heckman's $\lambda$ & $\begin{array}{c}-5.6812 * * \\
(-1.89)\end{array}$ & $\begin{array}{c}-5.0622^{*} \\
(-1.66)\end{array}$ \\
\hline Market Volatility & $\begin{array}{c}0.1377 \\
(0.99)\end{array}$ & $\begin{array}{c}0.1487 \\
(1.07)\end{array}$ \\
\hline Stock Volatility & $\begin{array}{c}0.0033 \\
(0.06)\end{array}$ & $\begin{array}{l}0.0082 \\
(0.17)\end{array}$ \\
\hline Stock Run Up & $\begin{array}{c}0.0962 * * * \\
(2.74)\end{array}$ & $\begin{array}{c}0.0887 * * \\
(2.46)\end{array}$ \\
\hline Turnover & $\begin{array}{c}-0.6999 \\
(-1.09)\end{array}$ & $\begin{array}{c}-0.5873 \\
(-0.91)\end{array}$ \\
\hline Relative Size & $\begin{array}{c}2.5912 \\
(1.47)\end{array}$ & $\begin{array}{l}2.8705 \\
(1.63)\end{array}$ \\
\hline Bank Size & & $\begin{array}{c}-0.1230 \\
(-0.17)\end{array}$ \\
\hline Equity & & $\begin{array}{l}1.0070 \\
(1.56)\end{array}$ \\
\hline$\triangle G D P p c$ & $\begin{array}{c}0.7880 \\
(1.61)\end{array}$ & $\begin{array}{c}0.8462^{*} \\
(1.71)\end{array}$ \\
\hline Country Fixed Effects & Yes & Yes \\
\hline Wald Test & $43.00 * * *$ & $48.00 * * *$ \\
\hline \# Observations & 96 & 96 \\
\hline
\end{tabular}

